REVISTA DE DERECHO UNED, NÚM. 22, 2018

\title{
MARCO REGULADOR, COMPETENCIAL Y ORGÁNICO EN LOS SUPUESTOS DE RESPONSABILIDAD INFRACTORA TRIBUTARIA
}

\author{
REGULATORY, COMPETENTIAL AND ORGANIC FRAME IN \\ RESPONSIBILITY CASES DUE TO TAX INFRINGEMENTS
}

\section{IVÁN PÉREZ JORDA}

Funcionario de Administración Local con habilitación de carácter nacional. Doctor en Derecho Financiero y Tributario. Profesor Asociado de Derecho Administrativo en la Universidad de Valencia. Licenciado en

Ciencias Políticas. Doctorando en Filosofía y Letras en la UNED.

Resumen: El presente artículo se analiza detenidamente los diferentes órganos competentes en el procedimiento sancionador tributario.

Abstract: This article analyses carefully diferent tax authorities for the tax penalties procedure.

Palabras clave: Órgano tributario, competencia, procedimiento sancionador tributario.

Keywords: Tax authority, power, sanctioning tax procedure.

Recepción original: 12/12/2017

Aceptación original: 20/02/2018

Sumario: I. Marco regulador y competencial de la potestad sancionadora tributaria. II. Marco orgánico 2.1. Procedimiento sancionador tributario realizado mediante tramitación separada. 2.1.1. Competencia objetiva. 2.1.2. Competencia Territorial. 2.1.3. Competencia por cambio de adscripción o de domicilio del obligado tributario. 2.1.4. Competencia para iniciar el procedimiento sancionado. 2.1.5. Competencia para instruir el procedimiento sancionador. 2.2. Procedimiento sancionador tri- 
butario realizado mediante tramitación conjunta. 2.2.1. En caso de que se inicie como consecuencia de un procedimiento inspector mediante acta con acuerdo. 2.2.2. En caso de que se inicie como consecuencia de renuncia a la tramitación separada. 2.3. Competencia para la terminación. 2.4. Competencia en los procedimientos de imposición de sanciones no pecuniarias. 2.5. Conclusión. Necesidad de separación orgánica entre procedimientos de aplicación de los tributos y sancionador tributario.

\section{MARCO REGULADOR Y COMPETENCIAL DE LA POTESTAD SANCIONADORA TRIBUTARIA}

Para el estudio concreto y correcto de la potestad sancionadora de carácter tributario, hemos de tener muy en cuenta el marco jurídico regulador de las competencias de las diferentes Administraciones con capacidad reguladora de la tipificación y sanción de la relación jurídico-tributaria ${ }^{1}$ formal $^{2}$ o material infringida.

\footnotetext{
${ }^{1}$ Son sujetos agentes de las infracciones tributarias todos aquellos que ocupan en las relaciones tributarias una situación pasiva. Todos aquellos sobre los que pesen deberes y obligaciones tributarias pueden, incumpliéndoles, cometer una infracción. . FERREIRO LAPATZA, J.J.: Curso de Derecho Financiero Español: Instituciones, Marcial Pons, Madrid, 2006, pág. 548; Hablar de sujeto activo en las infracciones de carácter tributario supone necesariamente aludir a la Administración tributaria, en cuanto titular del crédito tributario, que en las infracciones con perjuicio económico, se ha dejado de ingresar. En las infracciones por incumplimientos de obligaciones formales también lo será la Administración Tributaria, a excepción de las previstas en los arts. 204 -que será el perceptor de las cantidades sujetas a retención-y 206 que será el obligado a quien el retenedor no entrega el certificado. GARBERÍ LLOBREGAT, J. (Dir.): Procedimiento Sancionador. Infracciones y Sanciones Tributarias. I, Tirant Lo Blanch, Valencia, 2005. págs. 655, 656, 702, 703, 779, 996, 1010, 1023, 1039, 1049 y 1059.

2 Por el contrario SIMÓN ACOSTA opina que las sanciones sólo formalmente pueden ser calificadas como crédito. Su estructura formal o externa es similar a la del crédito, así la Administración, de un lado, tiene derecho a exigir a otra, el infractor, una cantidad de dinero. Pero su fundamento y razón de ser y su esencia son radicalmente diferentes. El crédito tributario es un derecho subjetivo, esto es, un interés jurídicamente protegido. El interés protegido es un interés patrimonial del sujeto obligado, interés que merece una tutela especial pues a través del mismo no solo se enriquece la Administración sino que se hace efectivo el deber de solidaridad. En cambio, la sanción es una medida represiva, un castigo, un sufrimiento que se provoca a una persona como compensación o retribución de la comisión de un ilícito y que tiene asimismo la finalidad de evitar que se repita la conducta antijurídica. No se protege o tutela un interés patrimonial de la Administración. La sanción no es un derecho subjetivo o interés patrimonial de la Administración que merezca la tutela del Derecho. La sanción es simplemente un mal causado al infractor, similar al que se le impone cuando se le priva de libertad. SIMÓN ACOSTA, E.: La nueva Ley General Tributaria, Civitas, 2004, pág. 715.
} 
Siguiendo a Merino Jara ${ }^{3}$, debemos diferenciar entre poder y potestad. El poder deriva directamente del texto constitucional, así el poder tributario, cuyo fundamento se encuentra en el deber de contribuir $^{4}$. La potestad ${ }^{5}$, supone la previa existencia de una Ley que confiera a la Administración la posibilidad de actuar válidamente en el terreno jurídico, así la sancionadora.

Actualmente, la Constitución Española de 1978 ha legitimado la potestad sancionadora de la Administración ${ }^{6}$ en sus artículos 25.1, 25.3 y 45.3, y sólo existe jurídicamente dentro de los límites de ésta ${ }^{7}$. En

\footnotetext{
${ }^{3}$ FUSTER ASENCIO, C.: El procedimiento sancionador tributario, Aranzadi, Navarra, 2001, pág. 19.

${ }^{4}$ Quien no estima válida, tras la Constitución de 1978, la distinción entre poder
} tributario originario y poder derivado. PÉREZ ROYO, F.: Derecho Financiero y Tributario. Parte General, Civitas, Madrid, 2009, pág. 77.

${ }^{5}$ Para LINDE PANIAGUA, quien conceptúa la potestad como poder de la Administración, las potestades y técnicas administrativas carecen de relevancia constitucional. Dicho de otro modo, son meros instrumentos subordinados a los mandatos de intervención. LINDE PANIAGUA, E.: Fundamentos de Derecho Administrativo. Del Derecho del Poder al Derecho de los ciudadanos, COLEX-Uned, Madrid, 2009, págs. 265 y 266; Para PAREJO ALFONSO, potestad son títulos de acción administrativa, referidos, normalmente, a organizaciones enteras, a Administración determinadas, bien a una sola de ellas, bien a varias al mismo tiempo, en el primer caso se habla de competencia exclusiva, en el segundo, concurrente o compartida (quien utiliza, consciente e indistintamente, potestad y competencia).PAREJO ALFONSO, L.:Derecho Administrativo. Instituciones Generales, Ariel, Barcelona, 2003, pág. 620; BERMEJO conceptúa la potestad sancionadora como una manifestación del poder jurídico de las Administraciones Públicas para el cumplimiento de sus fines, ...represivo...preventivo...e intimidatorio. AA.VV. (Dir.: BERMEJO VERA, J.): Derecho Administrativo. Parte Especial, Civitas, Madrid, 1999, pág. 77; ESEVERRI define las potestades financieras como aquellas funciones, tanto facultades como deberes de actuar, con que cuentan las distintas Administraciones Públicas para poder aplicar a cada caso concreto el régimen jurídico vigente para generar el ingreso correspondiente o producir la erogación o gasto pertinente. ESEVERRI MARTÍNEZ, E. y LÓPEZ MARTÍNEZ, J.: Temas prácticos de derecho financiero, Comares, Granada, 2000, pág. 60.

${ }^{6}$ Diferenciándola así del pasado donde nadie duda de su existencia aunque si de su legitimidad. NIETO GARCÍA, A.:Derecho Administrativo Sancionador, Tecnos, Madrid, 1994, págs. 49 y ss. La conexión directa de la potestad sancionadora con el poder punitivo del Estado, permite superar la viaja idea de la subordinación del Derecho Administrativo Sancionador al Derecho Penal. La potestad administrativa sancionadora, está subordinada al poder judicial, no por ser sancionadora, sino por ser administrativa, y todas las actuaciones administrativas están sujetas al control de los Tribunales, pero de los contencioso-administrativos, no de los penales. NIETO GARCÍA, A....op. cit. pág. 165; Para BERMEJO no existe en el texto constitucional una cobertura expresa de la potestad sancionadora de la Administración Pública, si bien puede hallarse una referencia indirecta en el precepto art. 25.3 CE. BERMEJO VERA, J. (Dir.) et alii: Derecho Administrativo, ...op. cit., pág. 78.

${ }^{7}$ PÉREZ ROYO, F.: Derecho Financiero... 2009, pág. 77. 
primer lugar ${ }^{8}$, resulta necesario que se produzca la atribución de la potestad sancionadora a la Administración, mediante norma con rango de Ley. Esta previsión no aparece expresamente recogida en el artículo 25.1 de la CE, ya que este último legitima esta potestad, pero no la atribuye, esta atribución deberá realizarse mediante norma con rango de Ley. La exigencia de Ley formal debe entenderse referida a la expresión «legislación vigente» del artículo 25.1 de la CE. En segundo lugar, resulta preceptivo que el ejercicio de la potestad sancionadora sea realizado por los órganos administrativos que la tengan atribuida.

Debe distinguirse entre Ente Público, en cuanto titular de la potestad normativa de creación de los tributos, y el Ente Público, en cuanto Administración que tiene atribuida la potestad de gestión, con independencia de quien sea el titular de la recaudación, y, finalmente, los Entes de carácter público titulares de la recaudación, siendo sólo a éstos últimos a los que, en puridad, y según parte de la doctrina9 ${ }^{9}$, cabe definir como sujetos agentes del tributo, y, por ende, sujeto pacientes ${ }^{10}$ de la infracción que del incumplimiento de una obligación dimana.

Desde otro punto de vista, el titular de la potestad sancionadora tributaria, con carácter general ${ }^{11}$, es el titular del poder ${ }^{12}$ financie-

${ }^{8}$ PAREJO ALONSO, L., JIMÉNEZ-BLANCO, A. y ORTEGA ALVAREZ, L.: Manual de Derecho Administrativo, Ariel, Barcelona, 1994.

${ }^{9}$ COLLADO YURRITA, M.A.(Dir.); LUCHENA MOZO, G.M.(coord.), et alii: Derecho Tributario. Parte General, Atelier, Barcelona, 2007, págs. 249 y 250; También MARTÍNEZ LAGO, M.A. y GARCÍA DE LA MORA, L.: Lecciones de Derecho Financiero y Tributario, Iustel, Madrid, 2009 pág. 313; En contra, GARBERÍ, para quien por sujeto titular del crédito habrá de entenderse aquellas administraciones que tienen atribuida la potestad de gestión, con independencia de quien sea el titular de la recaudación. GARBERÍ LLOBREGAT, J. et alii: Procedimiento Sancionador... op. cit. págs. 702,703 y 779 .

${ }^{10}$ También en el ámbito penal, sujeto pasivo es la Hacienda Pública; y aunque la especificación hecha por el CP «estatal, autonómica y local», pudiera entenderse que deja fuera a la Hacienda de los entes públicos menores de carácter no territorial y con personalidad distinta de la Administración de que dependen, debe considerarse que la Hacienda Pública es la Hacienda de todos los entes públicos y que la Hacienda estatal, autonómica y local abarca la de los entes públicos menores que de ellas dependen y que pueden ser acreedoras de un tributo cuando así lo determine la Ley (art. 4.3 LGT). FERREIRO LAPATZA, J.J.: Curso de Derecho ...2006, op. cit.pág. 565.

${ }^{11}$ En algunos casos no sucedía, como el previsto en el artículo 42 del Real Decreto $754 / 2005$, de 24 de junio, por el que se regula el régimen de la tasa láctea, para la que [e]l órgano competente para la imposición de sanciones será la autoridad competente de la comunidad autónoma, pese a que la regulación es estatal (disposición hoy derogada por el Real Decreto 319/2015, de 24 de abril y por la Ley 6/2015, de 12 de mayo, de Denominaciones de Origen e Indicaciones Geográficas Protegidas de ámbito territorial supraautonómico).

${ }^{12}$ Las potestades administrativas son poderes jurídicos reconocidos abstracta y expresamente por el ordenamiento, que atribuyen a la Administración titular de los 
ro $^{13}$ o tributario ${ }^{14}$ infringido. Por tanto es preciso conectar el término poder financiero con la actividad financiera que han de desarrollar los entes públicos ${ }^{15}$, en la medida en que el ejercicio de

mismos una habilitación para desarrollar actuaciones ejecutivas concretas, productoras de efectos actuales o potenciales sobre la esfera de los administrados, en un ámbito más o menos determinado, tendentes a la satisfacción del interés general. MELÓN MUÑ́́Z, A. (Dir.): Memento Práctico Administrativo, Francis Lefevbre, Madrid, 2009, pág. 83; Para BERMEJO el ejercicio de la potestad sancionadora corresponde en exclusiva a la Administración Pública, excluida la potestad represiva de hacer ejecutar lo juzgado en los procesos penales atribuida al poder judicial. BERMEJO VERA, J. et alii: Derecho Administrativo, ... op. cit., pág. 77; Para ESEVERRI, citando a RODRÍGUEZ BEREIJO, en el siglo XIX se produce la normativización del poder, de modo que el poder financiero se transforma en poder normativo en materia financiera, y en consecuencia, el poder tributario, en poder normativo en materia tributaria. ESEVERRI MARTÍNEZ, E. y LÓPEZ MARTÍNEZ, J.: Temas prácticos ... op. cit., 2000, pág. 59.

${ }^{13}$ El término poder financiero ha de ser definido como el conjunto de competencias, potestades administrativas, atribuidas constitucionalmente a los entes públicos territoriales -Estado, Comunidades Autónomas y Entidades Locales- con la única finalidad de lograr la satisfacción del interés general dentro de su ámbito territorial. COLLADO YURRITA, M.A., et alii: Derecho Tributario...op. cit. pág. 105; Tan originario es el poder financiero del Estado como el de los demás Entes territoriales inferiores. MARTÍNEZ LAGO, M.A. y GARCÍA DE LA MORA, L.: Lecciones...op. cit. pág. 95; Poder financiero es el conjunto de prerrogativas que el ordenamiento jurídico concede a los entes públicos para el desempeño de sus funciones financieras (MAYER)...su atribución corresponde al ordenamiento jurídico. En este sentido se considera que el poder financiero del Estado, en cuanto manifestación de su soberanía, es originario en cuanto a su fundamento y autónomo en su configuración y ejercicio. En el ámbito interno, la organización territorial del Estado afecta a la estructura jurídica del poder financiero, graduándose entre poder originario (estatal) y derivado (CCAA y EELL), aunque en contra de tal distinción se posiciona MARTÍN QUERALT. BAYONA DE PEROGORGO, J.J; SOLER ROCH, M.T.: Materiales de Derecho Financiero, Compás, Alicante, 2010, págs. 83, 84 y 91; El poder tributario no es sino una especie dentro del género poder financiero, y éste es definido como el conjunto de competencias, potestades administrativas, atribuidas constitucionalmente a los entes públicos territoriales con la única finalidad de lograr la satisfacción del interés general dentro de su ámbito territorial. COLLADO YURRITA, M.A. y otros: Derecho Tributario...op. cit. pág. 105.

${ }^{14}$ El poder tributario es sólo aquel aspecto del poder financiero que se circunscribe a la vertiente de los ingresos pero, única y exclusivamente, de los ingresos de naturaleza tributaria, no a los demás ingresos no tributarios, ni al gasto público; para CALVO ORTEGA el Poder Tributario es un conjunto de potestades atribuidas por el ordenamiento a determinadas instituciones públicas (Parlamento y Poder Ejecutivo) y a entes públicos territoriales cuya concreción depende de la organización político-territorial del Estado mismo, en nuestro ordenamiento CCAA y Municipios. Hay tantos poderes tributarios como ordenamiento, aunque no todos tengan el mismo contenido y todos ellos cuenten con algunas fuentes o normas comunes. CALVO ORTEGA, R.: Curso de Derecho Financiero. Derecho Tributario. Parte General, Civitas, Madrid, 2001, pág. 123.

${ }^{15}$ Repárese en que las situaciones jurídicas que mencionamos se suceden en el plano de la aplicación o exigencia de los tributos, y no en el del establecimiento de ellos, extremo este último que se explica bajo la categoría del poder tributario. CAZORLA PRIETO, L.M.: Derecho Financiero y Tributario, Aranzadi, Navarra, 2004, págs. 349 y 350. 
esa actividad financiera determina la atribución de poder financiero, entendido como el conjunto de competencias cuyo desempeño ha de ir orientado a la satisfacción de los fines y necesidades públicas que la justifican. La determinación de este Poder Tributario debe hacerse separándolo de la situación jurídica de acreedor tributario, conceptos que, a veces, aparecen mezclados, más la Administración, debemos reconocer, es un acreedor privilegiado.

En nuestro ordenamiento jurídico, las manifestaciones del Poder Tributario $^{16}$ —establecimiento de tributos, potestad reglamentaria, de organización, de interpretación, de decisión de pretensiones contra la propia gestión y actividad de inspección (investigación) - tienen su legitimación constitucional, así el establecimiento de tributos, en los artículos 31 y 33 de la $\mathrm{CE}$, y, para las otras, a través de habilitaciones específicas a la Administración Pública, que son válidas obviamente para la Administración Tributaria, en los artículos 97, 98 y 103 de la $\mathrm{CE}^{17}$.

En la generalidad de los casos el ente público acreedor-infringido, es el mismo que establece y gestiona el tributo. Pero esto no sucede en todos los supuestos. No sucede en el caso de las Administraciones menores de carácter institucional que, conforme al art. 4.3 de la Ley 58/2003, de 17 de diciembre, General Tributaria (LGT) no pueden establecer tributos pero sí exigirlos cuando la Ley así lo determine (colegios profesionales, Cámaras de Comercio, Comunidades de Regantes). No sucede tampoco cuando el Estado establece un tributo que cede después a otro ente territorial (así los impuestos cedidos ${ }^{18}$ a las Comunidades Autónomas que la Ley 8/1980, de 22 de septiembre, de Financiación de las Comunidades Autónomas (LOFCA), define como impuestos «establecidos y regulados por el Estado, cuyo producto corresponde a la Comunidad

${ }^{16}$ Existe acuerdo doctrinal al considerar que el poder financiero en nuestro Ordenamiento presenta una estructura compleja, ya que el mismo queda repartido entre el Estado, las Comunidades Autónomas y las Corporaciones Locales, si bien no existe acuerdo sobre el alcance o el grado con que en cada caso se ejerce dicho poder, y muy concretamente el poder tributario. ESEVERRI MARTÍNEZ, E. y LÓPEZ MARTÍNEZ, J.: Temas prácticos ...op. cit., 2000, pág. 63.

${ }^{17}$ Poder Tributario comunitario lo denomina CALVO ORTEGA, R.:Curso de Derecho...op. cit.2001, págs. 123 y 124.

${ }^{18}$ En relación con este tema hay que tener en cuenta, en primer lugar, que la titularidad de las competencias normativas y de aplicación de los impuestos cuyo rendimiento se cede, total o parcialmente a las Comunidades, corresponde al Estado, así como la potestad sancionadora y la de revisión de los actos dictados en ejercicio de esas competencias (art. 45.1 Ley 22/2009). MARTÍN QUERALT, J.; TEJERIZO LÓPEZ, J.M. ${ }^{\text {a }}$; CAYÓN GALIARDO, A. (Dirs.): Manual de Derecho Tributario. Parte Especial, Thomson-Aranzadi, Navarra, 2011, pág. 739. 
Autónoma»). Ni cuando el Estado crea un tributo a favor de los Municipios reservándose él su gestión, o cuando el Estado atribuye a otro ente público la posibilidad de establecer un recargo sobre el tributo estatal. El acreedor, caso de que sea utilizada esta posibilidad, el sujeto agente de la obligación y paciente de la infracción tributaria que determina el recargo- el titular del derecho de crédito u obligación infringida- es el ente que establece el recargo, pero el Estado es el único que puede y debe gestionarlo, cobrarlo, recaudarlo, sancionarlo, debiendo entregar después las sumas recaudadas al municipio acreedor.

Según los apartados 2 y 3 del artículo 5 de la LGT, en el ámbito de competencias del Estado, la aplicación de los tributos, el ejercicio de la potestad sancionadora y la función revisora en vía administrativa corresponde al Ministerio de Economía y Hacienda ${ }^{19}$, en tanto no haya sido expresamente encomendada por Ley a otro órgano o entidad de derecho público. Así, en los términos previstos en su Ley de creación ${ }^{20}$, dichas competencias corresponden a la Agencia Estatal de Administración Tributaria, salvo la declaración de nulidad de pleno derecho regulada en el artículo 217 y las reclamaciones económico-administrativas reguladas en el capítulo IV del título V de la presente Ley. Las Comunidades Autónomas ${ }^{21}$ y las entidades locales ejercerán las competencias relativas a la aplicación de los tributos y el ejercicio de la potestad sancionadora derivada de dicha aplicación, así como la función revisora en vía administrativa de los actos dictados en el ejercicio de aquellas, con el

${ }^{19}$ Ello supone residenciar el ejercicio de la potestad sancionadora ante un órgano que presenta la doble condición de político y jerárquicamente superior de la Administración, evitando el carácter político de épocas pretéritas. ANEIROS PEREIRA, J.: Las sanciones tributarias, Marcial Pons, Madrid, 2005, pág. 193.

${ }^{20}$ En análogo sentido el art. 47 de la Ley 47/2003, de 26 de noviembre, General Presupuestaria. La AEAT fue creada por el art. 103 de la Ley 31/1990, de 27 de diciembre de Presupuestos Generales del Estado para 1991; hasta dicho momento la Administración financiera no se diferenciaba como persona jurídica de 1 Administración pública general del Estado...La Agencia nace, ex art. 103.uno.1 de la referida Ley, como un ente de Derecho Público, el actual, aunque adscrito a la Secretaría de Estado de Hacienda y Presupuestos, está dotado de personalidad jurídica propia y plena capacidad jurídica pública y privada, cuyo objetivo es la aplicación efectiva del sistema tributario (art. 103.uno.2), rigiéndose en el desempeño de sus funciones tributarias por lo dispuesto en la LGT y en la LRJPAC (hoy Leyes 39 - LPACAP-y 40/2015, de 2 de octubre - LRJSP-). CAZORLA PRIETO, L.M.: Derecho Financiero...op. cit. págs. 83, 85 y 86.

${ }^{21}$ Que también podrán crear sus propias Agencias Tributarias. CAZORLA PRIETO, L.M.: Derecho Financiero... op . cit. pág. 88; BAYONA DE PEROGORDO, J.J. y SOLER ROCH, M.T.: Materiales... op. cit. pág. 106.

(C) UNED. Revista de Derecho UNED, núm. 22, 2018 
alcance y en los términos previstos en la normativa que resulte aplicable y su sistema de fuentes ${ }^{22}$.

La titularidad genérica del poder tributario es propia del Estado en acepción amplia, es decir, dentro de nuestro ordenamiento jurídico, del Estado ${ }^{23}$ en sentido estricto, de las Comunidades Autónomas ${ }^{24}$ y de las Corporaciones Locales ${ }^{25}$.

${ }^{22}$ En la gestión tributaria de los Impuestos sobre el Patrimonio, sobre Sucesiones y Donaciones, sobre Transmisiones Patrimoniales y Actos Jurídicos Documentados, de los Tributos sobre el Juego, del Impuesto Especial sobre Determinados Medios de Transporte y del Impuesto sobre las Ventas Minoristas de Determinados Hidrocarburos corresponderá a las Comunidades Autónomas: c) La calificación de las infracciones y la imposición de sanciones tributarias. (art.55.1.c Ley 22/2009 en relación al art. 19.2 LOFCA)

${ }^{23}$ El Poder Tributario del Estado se encuentra reconocido en el artículo 133.1 CE: «La potestad originaria para establecer tributos corresponde exclusivamente al Estado, mediante ley»....la calificación constitucional del poder tributario del Estado como originario (o supremo o primario o preeminente) legitima la precedencia de éste sobre el de las Comunidades Autónomas en caso de colisión acerca de la materia sobre la que ejercer el poder tributario con el establecimiento de tributos. Esta condición del poder tributario se relaciona con otros preceptos de la propia Constitución.....Nos referimos a la competencia exclusiva sobre «Hacienda General» (art.149.1.14) que legitima la intervención del Estado en la regulación del marco general de todo el sistema tributario....La competencia de armonización del ejercicio de las competencias financieras de las CCAA que el artículo 157.3 atribuye al Estado, que debe ejercerla mediante Ley Orgánica. La STC 192/2000 resalta la indudable conexión existente entre los artículos 133.1, 149.1.14 y 157.3 de la Constitución (que) determina que el Estado sea competente para regular no sólo sus propios tributos, sino también el marco general de todo el sistema tributario y la delimitación de las competencias financieras de las Comunidades Autónomas respecto de las del propio Estado. PÉREZ ROYO, F.: Derecho Financiero..., 2009, op. cit. pág. 78.

${ }^{24}$ Que se reconoce a las Asambleas legislativas no de las Comunidades del art. 151 $\mathrm{CE}$, sino también a las del art. $152 \mathrm{CE}$ cuyos Estatutos recogieron dicha potestad como fuente de financiación, sin perjuicio que pueda también ejercitarse a través de legislación armonizadora — cuyo blindaje estatutario está prohibido (art. 157.3 CE—. ...a la vista de esta potestad de armonización...el mandato del artículo 133.2, en lo que se refiere al poder tributario autonómico, debería ser leído en los siguientes términos: Las Comunidades Autónomas ejercerán su poder tributario de acuerdo con la Constitución y sus Estatutos y dentro de los términos previstos, en su caso, por la Ley Orgánica a que se refiere el artículo 157.3. PÉREZ ROYO, F.: Derecho ...2009, op. cit. pág. 80 .

${ }^{25}$ CAZORLA PRIETO, L.M.: Derecho Financiero...op. cit. pág. 70; De acuerdo con el apartado 2 del art. 6 de la LOFCA, los tributos establecidos por las Comunidades Autónomas no podrán recaer sobre hechos imponibles gravados por el Estado. De acuerdo con la redacción original del apartado 3, esos tributos tampoco podían recaer sobre las materias que la legislación de régimen local reservara a las Corporaciones Locales, salvo en los supuestos en que esta legislación lo previera (supuestos delimitados de manera muy restrictiva por la DA 1. ${ }^{a}$ del RDLg. 2/2004). La LO 3/2009, de 18 de diciembre, ha modificado, entre otros preceptos, el citado artículo 6. De acuerdo con la redacción hoy vigente del 
La categoría del poder financiero ${ }^{26}$, en cuanto ente capaz de realizar el establecimiento o aprobación de ingresos y gastos públicos, otorga un sentido unitario a las distintas situaciones jurídicas activas que se pueden dar cita en tal campo. El poder financiero en cuanto, ente capaz de exigir o aplicar lo previamente establecido y aprobado, corresponde, en distinto grado, a las categorías de los derechos subjetivos, las potestades financieras-incluida la punitiva-, la relación jurídica y el procedimiento — también el sancionador ${ }^{27}$.

El poder financiero actúa, en primer lugar, en un plano abstracto, significando la emanación de normas jurídicas que disciplinan los ingresos y los gastos del Estado y demás entes públicos. En un plano concreto, significa aplicación de estas normas jurídicas. En este plano, corresponde a la Administración financiera la aplicación de tales normas. La Administración financiera puede ser entendida como el conjunto de órganos administrativos a quienes corresponde normalmente la realización de la actividad financiera, y en cuanto tal actividad, puede ser desarrollada por los diversos entes públicos que conoce nuestro ordenamiento, podemos hablar así de Administración financiera del Estado, de las Comunidades Autónomas, de las entidades locales y de los entes públicos institucionales ${ }^{28}$.En ese orden de cosas, colegimos que dispondrán de potestad sancionadora, al poderse reclamar en vía económico-administrativa la imposición de sanciones tributarias que realicen la Administración General del Estado y las entidades de derecho público vinculadas o dependientes de la misma y las Administraciones tributarias de las Comunidades Autónomas y de las Ciudades con Estatuto de Autonomía (art. 226.a LGT).

apartado 3, los tributos propios de las Comunidades Autónomas no podrán recaer sobre hechos imponibles gravados por los tributos locales, pero sí podrán hacerlo sobre «las materias que la legislación de Régimen Local reserve a las Corporaciones Locales». Como se señala en la Exposición de Motivos de la citada LO, esta modificación pretende que las reglas de incompatibilidad se refieran al hecho imponible y no a la materia imponible, con lo que habría un espacio fiscal autonómico más claro en relación con los tributos locales, con una delimitación similar a la que existe en relación con los tributos estatales. MARTÍN QUERALT, J.; et alii (Dirs.): Manual ..., 2011, op. cit. pág. 745.

${ }^{26}$ Agrupa bajo el concepto "competencias financieras» el contenido global de las potestades tanto normativas como aplicativas o de ejecución de que gozan los entes públicos territoriales. MARTÍNEZ LAGO, M.A. y GARCÍA DE LA MORA, L.: Lecciones...op. cit. pág. 96.

${ }^{27}$ CAZORLA PRIETO, L.M.: Derecho Financiero...op. cit. pág. 82.

${ }^{28}$ FERREIRO LAPATZA, J.J.: Curso de Derecho...op. cit. 2006, págs. 84 y 85. 
Aunque bien poco afecte al objeto este estudio, dejaremos constancia de la atribución del ejercicio de competencias normativas, también en materia tributaria europea, que otorgaron las Cortes Españolas mediante Ley Orgánica 10/1985, de 2 de agosto, por la que España se adhirió a las Comunidades Europeas ${ }^{29}$.

Tanto el Tribunal Constitucional, en su STC 77/1983, como el Tribunal Europeo de Derechos Humanos, en su STEDH de 21 de febrero de 1984 (caso Oztürk contra la República Federal Alemana), han manifestado la conveniente existencia de una potestad sancionadora en manos de la Administración, puesto que el ejercicio de la misma con relación a ilícitos de menor gravedad, dotaría de mayor eficacia a la Jurisdicción ${ }^{30}$.

Conforme al artículo 25.3 de nuestra Carta Magna, la Administración Civil no podrá imponer sanciones que, directa o subsidiariamente, impliquen privación de libertad, reconociendo así la titularidad de la potestad sancionadora ${ }^{31}$ a la Administración Pública.

El poder tributario ${ }^{32}$ se distribuye, conforme marcan los artículos 133 y 137 de la Constitución Española, de modo que además de la potestad originaria ${ }^{33}$ de establecer tributos del Estado, éste se or-

\footnotetext{
${ }^{29}$ Poder Tributario comunitario lo denomina CALVO ORTEGA, R.:Curso de Derecho Financiero....op. cit., pág. 125.

${ }^{30}$ HERMOSÍN, M.: Procedimiento sancionador tributario. Cuestiones problemáticas, Asociación Española de Asesores Fiscales. Thomson-Aranzadi, Navarra, 2008, pág. 29.

${ }^{31}$ También se recoge el poder punitivo de la Administración, entre otros, en los arts. 9.3 y 45.3 de la CE.

${ }^{32}$ Dicha diferenciación debe interpretarse en el sentido de que el Estado tiene como único límite la Constitución, mientras que las Comunidades Autónomas y las Entidades Locales su límite está en la Constitución y en las Leyes. PÉREZ DE AYALA, J.L. y PÉREZ DE AYALA BECERRIL, M.: Fundamentos de Derecho Tributario, Edersa, Dijusa, Madrid, 2004, págs. 37 y 38.

${ }^{33}$ Es preciso conectar el término poder financiero con la actividad financiera que han de desarrollar los entes públicos territoriales en la medida en que el ejercicio de esa actividad determina la atribución de poder financiero, entendido como el conjunto de competencia cuyo desempeño ha de ir orientado a la satisfacción de los fines y necesidades públicos que la justifican....El poder tributario es sólo aquel aspecto del poder financiero que se circunscribe a la vertiente de los ingresos, pero única y exclusivamente de los ingresos de naturaleza tributaria...Por consiguiente, el poder tributario ha de ser entendido como la potestad para establecer, aplicar y recaudar tributos. COLLADO YURRITA, M.A. y otros: Derecho Tributario...op. cit. pág. 106; La Constitución lleva a cabo una distribución vertical del poder público entre entidades de distinto nivel, que son fundamentalmente el Estado, titular de la soberanía, las Comunidades Autónomas, caracterizadas por su autonomía política, y las provincias y municipios, dotados de autonomía administrativa de distinto ámbito. (STC 32/1981, FJ.3º);En la actualidad más que poder originario o derivado en función del texto normativo que lo
} 
ganiza territorialmente en municipios, en provincias y en las Comunidades Autónomas que se constituyan. Todas estas entidades gozan de autonomía para la gestión de sus respectivos intereses, pero las Comunidades Autónomas no pueden ${ }^{34}$ invadir el campo de acción de los impuestos estatales, pero el Estado sí puede invadir, como reconoce el artículo 6.4 de la LOFCA, el campo de acción de los impuestos autonómicos. La potestad originaria del Estado para establecer tributos, reconocida en el artículo 131.1 de la Constitución, supone que el Estado sólo está condicionado en este terreno por la propia Constitución. El principio de coordinación con la Hacienda del Estado condiciona el establecimiento de tributos autonómicos al respecto del sistema estatal.

Del tenor de los preceptos transcritos se extrae quienes son los titulares del poder tributario en España, cuyas Administraciones ${ }^{35}$ serán

atribuye, se habla de poder originario de primer o segundo grado (Lasarte); de poder originario y subordinado (J.L. MUÑ́́Z); de potestad legislativa de primer o segundo grado y condicionada (Ramallo); pero casi todos coincidimos en fijar nuestra preferente atención en los contenidos y los límites de las respectivas competencias (Pérez de Ayala y Eusebio González). ESEVERRI MARTÍNEZ, E. y LÓPEZ MARTÍNEZ, J.: Temas prácticos ...op. cit., pág. 64.

${ }^{34}$ FERREIRO LAPATZA, J.J. y SARTORIO ALBALAT, S.: Curso de Derecho Financiero Español, vol. III. Derecho Tributario: Parte Especial, Marcial Pons, Madrid, 2004, pág. 310.

${ }^{35}$ Según la STSJ de Valencia de 13 de octubre de 2009, FJ CUARTO., Hemos de acudir a otra perspectiva más amplia, la de la titularidad del ius puniendi. Como es conocido, la facultad que en Derecho tienen las Administraciones Públicas de sancionar, de castigar a los administrados, caso de que éstos se conduzcan conforme a determinados patrones antijurídicos, es rasgo característico del Ordenamiento Español: así ha sido incluso después de la promulgación de la vigente Constitución de 1978, cuando, en contra de opiniones significadamente autorizadas, es reconocido expresamente el poder de la Administración para imponer sanciones (art. 25, apartados 1 y 3 ). Así es aun cuando ello implique una modalización de la estricta la división de los poderes del Estado, en la cual la potestad sancionadora debería constituir un monopolio judicial. En fin, la potestad administrativa de sancionar, en nuestro Ordenamiento, no ostenta el mismo rango que la de los jueces, sino que más bien ésta es originaria y la segunda coyuntural o auxiliar y en última instancia controlada por los jueces (art. 106.1 CE y STC 77/1983 ). Esto último no quiere decir que los órganos judiciales contencioso-administrativos ejerzan el ius puniendi asignado a la Administración. Ya advirtió el Tribunal Constitucional que no existe un proceso contencioso-administrativo sancionador en donde haya de actuarse el ius puniendi del Estado, sino un proceso administrativo cuyo objeto lo constituye la revisión de un acto administrativo de imposición de una sanción adoptada en un procedimiento que ha de ser respetuoso con las principales garantías del art. 24 CE (STC 89/1995, FJ 4 ); no son los Tribunales contencioso-administrativos quienes, al modo de lo que sucede en el Orden jurisdiccional penal, sancionan al administrado, pues la sanción administrativa la impone siempre la Administración pública «...en el ejercicio de la potestad que le reconoce la Constitución»(STC 59/2004, FJ 3 ).QUINTO., Sólo una decisión definitiva del 
las que podrán hacer valer dicha potestad punitiva, y que son la del Estado (art. 133.1 CE y 4.1 LGT) ${ }^{36}$, las de las Comunidades Autónomas (arts. 133.2, 138, 156.1, 157.3, $158 \mathrm{CE}$ ), y las de los municipios, Provincias y demás Entidades Locales reguladas en la legislación de régimen local (arts. 133.2, 137, 141, $142 \mathrm{CE})^{37}$. Así mientras, para la normación de las potestades tributarias y sancionadoras, el Estado se ve compelido a la observancia exclusiva de los límites que la Constitu-

Poder Público investido de ius puniendi será la que enerve la presunción interina de inocencia, lo cual impone que el proceso penal o el procedimiento sancionador se hayan culminado en todas sus fases, también las de recurso o impugnativas. Dado que en nuestro Ordenamiento cabe, frente a las resoluciones administrativas, recurso jurisdiccional -el contencioso-administrativo (arts. 106.1 CE y 9.4 LOPJ)—, y también recurso de amparo constitucional contra las decisiones judiciales confirmatorias de aquéllas y las mismas condenas penales de los jueces - aunque sólo por vulneración de derechos fundamentales (art. 53.2 CE y $41 \mathrm{LOTC}$ )-, es de plantearse hasta qué momento el ciudadano disfruta del manto protector de la presunción de inocencia. Pues bien, en coherencia con la peculiaridad de nuestro sistema, conforme al cual la Potestad Sancionadora viene atribuida tanto a la Administración como a los jueces del Orden Penal, habrá que entender que la presunción de inocencia sólo se mantendrá hasta que se alcance una resolución Centro de Documentación Judicial sancionadora definitiva en el ámbito correspondiente; el administrativo en el primer caso, y una sentencia condenatoria firme dentro del proceso penal en el segundo, ello sin perjuicio de que las facultades revisoras de los jueces contencioso-administrativos y Tribunal Constitucional puedan dejar sin efecto una y otra.

${ }^{36} \mathrm{Si}$ bien el Estado, según el artículo 149.1.14 de la Constitución, tiene competencia exclusiva sobre la Hacienda General, la Hacienda General no puede identificarse tampoco con toda la Hacienda pública, esto es, con la Hacienda no general. FERREIRO LAPATZA, J.J.: Curso de Derecho...op. cit. 2006, pág. 73.

${ }^{37}$ Algún autor añade la Administración Institucional , precisando que a veces la titularidad de la competencia normativa (del poder tributario) - creación del tributo- y del crédito tributario - aplicación del tributo y su sanción- no coinciden, porque son aspectos que hacen referencia a realidades distintas y a dos momentos diferentes de la vida del tributo, p.ej. en los tributos gestionados por entes institucionales, o cuando el Estado cede determinados tributos a las Comunidades Autónomas, o cuando aquél crea un gravamen a favor de los municipios, reservándose su gestión, o cuando posibilita que otros entes establezcan un recargo sobre un tributo estatal. MARTÍNEZ LAGO, M.A. y GARCÍA DE LA MORA, L.: Lecciones...op. cit. págs. 313 y 314; Si bien las demás entidades de Derecho público no pueden establecer tributos, sólo pueden exigirlos, el esquema no se cumple con absoluto rigor en el ordenamiento vigente. Así sucede con los entes públicos que integran nuestra administración institucional de base corporativa (Colegios profesionales, Cámaras de Comercio, Comunidades de Regantes) pueden establecer cuotas y otros ingresos cuyo carácter tributario se reconoce hoy por la mayoría de la doctrina. Y esta posibilidad viene, en determinados casos, atribuidas a estas Corporaciones por normas de carácter reglamentario, lo que es contrario a las normas que en nuestra Constitución consagran el principio de legalidad y regulan el poder de establecer tributos, y es contrario, asimismo, al mandato contenido, a nivel de Ley ordinaria, en el art. $4^{\circ}$ LGT. FERREIRO LAPATZA, J.J.: Curso de Derecho... op. cit.. 2006, pág. 83. 
ción le impone, las Comunidades Autónomas han de observar, además, los límites impuestos por las leyes estatales ${ }^{38}$.

El marco constitucional en el que se mueven el poder financiero del Estado y de las Comunidades Autónomas, lejos de establecer un modelo "cerrado» de reparto del poder financiero, dibuja un cuadro o espacio «abierto» en el que caben múltiples y muy diversas posibilidades de concreción ${ }^{39}$.Creemos acertada la opinión de Carrera Raya $^{40}$, cuando afirma que la Hacienda general comprende la estatal y sus relaciones con la Hacienda de las Comunidades Autónomas y de las Corporaciones locales, en cuanto esas relaciones son expresivas de principios constitucionales como los de coordinación y de solidaridad.

La Constitución nada dice sobre el poder financiero de los entes institucionales ${ }^{41}$ o Entes de Derecho público, que el artículo 4 de la LGT, autoriza a exigir ${ }^{42}$ tributos, cuando una Ley así lo determine, y en la forma y en los casos que allí se establezca. De este modo la LGT se muestra plenamente conforme al artículo 133 de la CE, pues sólo el Estado, Comunidades Autónomas y Entes Locales pueden estable-

${ }^{38}$ Así, el art. 6 LOFCA coloca al sistema tributario estatal como primer límite de los impuestos propios de las Comunidades Autónomas. Pero al cumplir esta función, el sistema tributario estatal también tiene sus propios límites...se trata de dejar sentado que la Constitución reserva un lugar a los impuestos propios de las Comunidades Autónomas y que el Estado debe ser consciente de esta reserva.... El estado no debe agotar todas sus posibilidades de imposición, sino que debe, por mandato de la Constitución, reservar a las Comunidades Autónomas un espacio en este terreno....Por su parte, las Corporaciones Locales - con potestad reglamentaria de establecimiento de la vigencia de tributos ya creados, no creadora de tributos- pueden, también, verse condicionadas en el establecimiento de la vigencia - dotando de fuerza efectiva- de tributos ya creados y prefigurados en sus líneas esenciales por la legislación autonómica y estatal. La Constitución no prohíbe desde luego a las Comunidades Autónomas legislar sobre esta materia ni la reserva expresamente y de forma exclusiva al Estado, pero la legislación autonómica está a su vez condicionada en materia de tributos, incluidos los tributos locales, por las leyes del Estado, en virtud del mandato constitucional establecido en el art. 133 de la Constitución. FERREIRO LAPATZA, J.J. y SARTORIO ALBALAT, S.: Curso de Derecho ... 2004, op. cit. págs. 311-315.

${ }^{39}$ FERREIRO LAPATZA, J.J.: Curso de Derecho...op. cit.2006, pág. 77.

${ }^{40}$ Citada por CARRERA RAYA, F.J.: Manual de Derecho Financiero. vol.I, Tecnos, 1993, Madrid, pág. 53.

${ }^{41}$ Para algún autor, dichos Entes carecer de Poder Financiero, pues sólo tienen competencia financiera. Su competencia financiera se agota en sujetos activos de la obligación tributaria. CARRERA RAYA, F.J.: Manual ...op. cit., págs. 65 y 66.

${ }^{42}$ Según ESEVERRI la competencia tributaria es aquella facultad que detentan determinados entes públicos y que le facultan para exigir tributos aunque no para establecerlos. ESEVERRI MARTÍNEZ, E. y LÓPEZ MARTÍNEZ, J.: Temas prácticos ... op. cit., pág. 60 . 
cerlos. Así, integran dicha Administración Institucional de base corporativa, los Colegios Profesionales, Cámaras de Comercio, Comunidades de Regantes, pero también podemos encontrar entes de carácter fundacional como Organismos autónomos, entidades públicas empresariales. El único reproche doctrinal a estos entes es que la posibilidad de exigir tributos les venga dada por normas de carácter reglamentario, contraviniendo el principio de legalidad consagrado constitucionalmente, incluso regulando el poder de establecer tributos, lo que conculca el artículo 4 de la $\mathrm{LGT}^{43}$.

En relación con los territorios de régimen foral, la Disposición Adicional 1. ${ }^{a} \mathrm{CE}$ se ampara y respeta los derechos históricos de los territorios forales. El País Vasco, por remisión de su Estatuto de Autonomía, aprobado por Ley Orgánica 3/1979, de 18 de diciembre, se rige por el sistema tradicional de Concierto Económico ${ }^{44}$, el actual

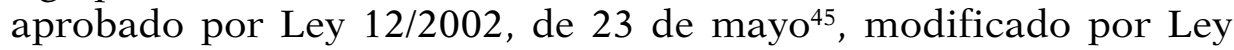

${ }^{43}$ FERREIRO LAPATZA, J.J.: Curso de Derecho...op. cit.2006, pág. 83.

${ }^{44}$ En el País Vasco, la Ley $12 / 2002$, de 23 de mayo, .....configura el Impuesto sobre Sociedades como un tributo concertado de normativa autónoma, cuya regulación corresponde a las instituciones competentes de los Territorios Históricos - las Diputaciones Forales - respetando los principios de armonización establecidos en el propio concierto. La normativa autonómica, se aplica, como regla general, a las entidades cuyo domicilio radica en el País Vasco. Tratándose de entidades cuyo volumen de operaciones en el ejercicio haya superado los 7 millones de euros anuales, se exige además que la entidad realice, en el País Vasco y en los términos especificados en el Concierto, más de 125 por 100 de sus operaciones. Asimismo, será de aplicación la normativa autónoma a las entidades cuyo domicilio fiscal radique en territorio común, su volumen de operaciones hubiera excedido de 7 millones de euros y hubieran realizado la totalidad de sus operaciones en el País Vasco. La exacción del Impuesto corresponde, en su integridad, a las Diputaciones Forales, cuando el domicilio fiscal se encuentre en el País Vasco y su volumen de operaciones no exceda de 7 millones de euros. Si el volumen de operaciones de la entidad supera el citado límite cuantitativo, cualquiera que sea el lugar donde radique su domicilio fiscal, tributarán a la Administración del Estado, a las Diputaciones Forales o a ambas Administraciones, en proporción al volumen de operaciones realizado en cada territorio. FERREIRO LAPATZA, J.J. MARTÍN FERNÁNDEZ, J.; RODRÍGUEZ MÁRQUEZ, J.; TOVILLAS MORÁN, J.M.: Curso de Derecho Tributario. Parte especial. Sistema Tributario. Los tributos en particular, Marcial Pons, Madrid, 2008, pág. 156.

${ }^{45} \mathrm{Su}$ artículo 1 expresa que los territorios históricos en la elaboración de la normativa tributaria se adecuarán a la Ley General Tributaria en cuanto a su terminología y conceptos, sin perjuicio de las peculiaridades establecidas en el presente Concierto Económico; El Concierto Económico atribuye a las Instituciones de los Territorios Históricos la competencia para mantener, establecer y regular, dentro de su territorio, su régimen tributario y prevé que, a la hora de elaborar la normativa tributaria foral únicamente tiene que adecuarse a la Ley General Tributaria en cuanto a terminología y conceptos. Esas normas forales equivalentes a la LGT estatal son: En Álava, la Norma Foral 6/2005 de 28 de febrero, General Tributaria de Álava, y la Decreto Foral 6/2006, de 6 de junio, por el 
28/2007, de 25 de octubre y complementado por Ley Orgánica 4/2002, de 23 de mayo que tiene carácter indefinido, y se basa en el sistema de cupo. Las instituciones competentes de los Territorios Históricos, las Juntas Generales de los tres territorios históricos o Diputaciones Forales (Álava, Vizcaya y Guipúzcoa ${ }^{46}$ —que no el Parlamento Vasco-, son las competentes para establecer y regular dentro de su territorio el régimen tributario, y que gestionan los tributos concertados de normativa autonómica ${ }^{47} y$ de normativa estatal ${ }^{48}$, mientras que los no concertados ${ }^{49}$ se gestionan por la Administración del Estado. A dicha regulación se remite el artículo $1.2^{\circ}$ de la LGT, tanto para el País Vasco como para Navarra.

que se aprueba el reglamento de inspección del territorio histórico de Álava; En Guipúzcoa, la Norma Foral 2/2005, de 8 de marzo, General Tributaria y el Decreto Foral 42/2006, de 26 de septiembre, por el que se aprueba el reglamento del régimen de infracciones y sanciones tributarias en Guipúzcoa y el Decreto Foral 64/2004. de 29 de junio, por el que se adapta lo dispuesto en la Ley 58/2003, en relación a las modificaciones del IVA y los IIEE en Guipúzcoa; En Vizcaya, la Norma Foral 2/2005, de 10 de marzo, General Tributaria, el Decreto Foral 99/2005, de 21 de junio, por el que se aprueba el Reglamento de Inspección y el Decreto Foral 100/2005, de 21 de junio, por el que se aprueba el reglamento sancionador tributario del Territorio Histórico de Vizcaya. AA.VV. (Coord. PELÁEZ MARTOS, J.M. ${ }^{a}$.): Todo procedimiento Tributario 2006, CISS, Valencia, 2006, págs. 992-993.

${ }^{46}$ La STS de 11.04.2013 resolvió un caso de conflicto de competencias donde, pese a que no trataba de asunto sancionador, sino de devolución tributaria de IVA, fue peculiar por cuanto las Administraciones Estatal y Foral se declaraban incompetentes para tramitar la devolución, y ninguna hiz declaración formal de incompetencia a favor de la otra, y como no cabía promover conflicto a la entidad interesada, formalmente no podía tenerse por planteado conflicto alguno entre ambas administraciones, perjudicando fatalmente el derecho de la parte recurrente que comprueba como teniendo derecho a la devolución del IVA — sin perjuicio de las comprobaciones a las que hubiera lugar - no se iba a hacer efectiva porque ninguna de las dos administraciones responsables había cumplido las formalidades precisas para el planteamiento del conflicto, y dado que las Administraciones no podían beneficiarse de su propio incumplimiento, en perjuicio del solicitante, la Junta Arbitral, y, ante la solicitud del interesado, antes que inadmitir la reclamación por motivos méramente procedimentales, debió requerir a las Administraciones y al solicitante para que aportaran los datos y antecedentes necesarios para resolver. La regulación de este tipo de conflictos se encuentra en el Real Decreto 1760/2007, de 28 de diciembre, por el que se aprueba el Reglamento de la Junta Arbitral prevista en el Concierto Económico con la Comunidad Autónoma del País Vasco.

${ }^{47}$ IRPF, IS, IP, ISD, ITPAJD, y Tributos sobre el juego.

${ }^{48}$ Por exigencias de armonización europea: IVA, IIEE; por mantener la uniformidad a nivel estatal: IRPFNR, I. Primas de Seguros y de Venta Minorista de determinados Hidrocarburos.

${ }^{49}$ Renta de Aduanas, incluyendo IVA e IIEE recaudados en Aduana; retenciones a funciones y empleados del Estado; retenciones de capital e activos emitidos por el Estado o las CCAA de régimen común; tasas afectas a servicios no asumidos por la Comunidad Vasca y las cotizaciones a la Seguridad Social. 
Igualmente, el territorio de $\mathrm{Navarra}^{50}$ se rige por el Convenio Económico, aprobado por Ley 28/1990, de 26 de diciembre ${ }^{51}$, cuyo texto refundido modificado fue aprobado por Ley 25/2003, de 15 de julio, modificado por las 14/2015, de 24 de junio y 48/2007, de 19 de diciembre, por la que se modifica la Ley 28/1990, de 26 de diciembre, por la que se aprueba el Convenio Económico entre el Estado y la Comunidad Foral de Navarra y complementado por Ley Orgánica 10/2003, de 15 de julio, que, con el carácter de complementaria a la Ley $25 / 2003^{52}$, de 15 de julio, por la que se aprue-

${ }^{50}$ La exposición de motivos de la Ley Foral General Tributaria 13/2000...afirma que la comunidad foral no es solamente titular de unos poderes concretos para regular los distintos tributos, sino que tiene potestad para mantener y regular un régimen tributario propio, un ordenamiento tributario, de manera que forma una unidad y un sistema, con capacidad de autointegración y con vocación de complitud. Ahora bien, la autonomía fiscal de Navarra debe armonizarse con el sistema estatal y lo hace precisamente a través del convenio económico. SIMÓN ACOSTA entiende que Navarra no tiene simplemente tributos propios, como los tienen las demás comunidades autónomas (art. 157.1.b CE), sino que tiene un régimen tributario propio, es decir, un ordenamiento jurídico tributario que, aunque derivado porque se integra en otro ordenamiento superior en el que funda su existencia, validez y vigencia, no es una simple yuxtaposición de normas, sino un conjunto sistemático que forma una unidad perfectamente identificable y - sobre todo- tiene capacidad de autointegración. PALAO TABOADA, C.: Comentario sistemático a la nueva Ley General Tributaria, CEF, Madrid, 2004, pág. 29; En lo que respecta al ámbito tributario, la Ley Foral 13/2000, de 14 de diciembre, General Tributaria, se erige en norma básica del ordenamiento tributario navarro, ... regula...las infracciones y sanciones tributarias. En [su]desarrollo ...se han dictado: El Decreto Foral 152/2001, de 11 de junio, por el que se aprueba el Reglamento de Inspección Tributaria, el Decreto Foral 153/2001, de 11 de junio, desarrolla las disposiciones de la Ley Foral General Tributaria en materia de infracciones y sanciones tributarias, y el Decreto Foral legislativo 1/2006, de 6 de febrero, de Armonización Tributaria, modifica las infracciones y sanciones tributarias tipificadas en la Ley Foral 19/1992, del Impuesto sobre el Valor Añadido, para armonizar el régimen sancionador del Impuesto de la Comunidad Foral con el de la actual normativa del impuesto en el régimen común. AA.VV. (Coord. PELÁEZ MARTOS, J.M. ${ }^{\text {. }}$ ):Todo procedimiento..op. cit.2006, pág. 992.

${ }^{51}$ De este modo, Navarra se ve obligada a adecuar sus normas tributarias a las exigencias penales establecidas cada una de las modificaciones del CP, v.gr. como ha ocurrido en la Ley Foral 14/2013, de 17 de abril, de Medidas contra el fraude fiscal.

${ }^{52}$ La normativa foral es de aplicación a las entidades que tributen exclusivamente en Navarra. Las que tributen, conjuntamente, a la Comunidad Foral y a la Administración Tributaria del Estado aplicarán la normativa correspondiente a la Administración de su domicilio fiscal. No obstante, aquéllas que, teniendo su domicilio fiscal en Navarra, realicen en territorio común más del 75 por 100 de sus operaciones, quedan sometidas a la normativa del Estado. La exacción del impuesto corresponde a la Comunidad Foral respecto de las entidades que tengan en ella su domicilio fiscal y su volumen de operaciones no exceda de 6 millones de euros y de aquéllas cuyo volumen de operaciones supere el límite indicado y operen, exclusivamente, en territorio navarro, cualquiera que sea el lugar donde radique su domicilio fiscal. Las que operen en ambos territorios y cuyo volumen de operaciones 
ba la modificación del Convenio Económico entre el Estado y la Comunidad Foral de Navarra, al amparo del artículo 45 de la Ley Orgánica 13/1982, de 10 de agosto, de reintegración y amejoramiento del régimen foral de Navarra, régimen también basado en el sistema de cupo ${ }^{53}$, aunque cuantificado de modo distinto al del País Vasco.

Desde la regulación establecida en 1990 para Navarra y en la reforma de 1997 del Concierto Económico con el País Vasco, solamente se establece una referencia a la normativa tributaria general en el Convenio y en el Concierto, que es la norma de armonización en virtud de la cual, las instituciones competentes de los territorios forales deben, a la hora de dictar su normativa propia, adecuarse a la Ley General Tributaria en cuanto a terminología y conceptos.

El alcance de esta limitación establecida al poder normativo de los territorios forales no es una cuestión pacífica ${ }^{54}$ desde el punto de vista jurídico, máxime cuando se producen diferencias, a veces importan-

sea superior a 6 millones de euros tributarán, conjuntamente, en ambas Administraciones, cualquiera que sea el lugar donde radique su domicilio fiscal, en proporción al volumen de operaciones realizado en cada territorio. FERREIRO LAPATZA, J.J. et alii: Curso de Derecho ....Los tributos en particular, ... 2008, op. cit. pág. 156.

${ }^{53} J T$ : «Reserva de ley, sanciones tributarias y relaciones en el ordenamiento foral navarro y el ordenamiento común», vol.II, BIB 1997 919; El carácter negociador de la financiación autonómica no es atributo exclusivo de las relaciones entre el Estado y las Comunidades Forales Vasca y Navarra, sino que se produce de igual forma con las Comunidades de régimen general. MARTÍNEZ LAGO, M.A. y GARCÍA DE LA MORA, L.: Lecciones...op. cit. pág. 103.

${ }^{54}$ Tanto el Concierto Económico con el País Vasco como el Convenio Económico con la Comunidad Foral de Navarra, como especificación dentro del bloque constitucional de lo dispuesto en la disposición adicional primera de la Constitución y en los respectivos Estatutos de Autonomía..., reconocen la competencia de las instituciones forales para mantener, establecer y regular su régimen tributario (además de regular sus competencias de exacción, gestión, inspección, liquidación, revisión y recaudación de los tributos que conforman su sistema tributario), sin más limitaciones que las derivadas de las reglas de armonización establecidas en los citados instrumentos jurídicos paccionados, así como las derivadas de la igualdad esencial de los ciudadanos reconocida en la Constitución y de la aplicación de los tratados y convenios internacionales que formen parte del ordenamiento jurídico interno a partir de su publicación completa en el Boletín Oficial del Estado. Estos principios, garantía esencial de la foralidad amparada por la disposición adicional primera de la Constitución, hacen que, en principio, cuando se reconoce autonomía normativa a las instituciones forales para regular una determinada materia, ello implica que pueden proceder a aprobar una regulación diferente a la establecida en territorio de régimen común. ALONSO ARCE, I.: "La prescripción tributaria y los ordenamientos forales», JT, 2005, BIB 2005\2021. 
tes, de regulación en aspectos sustanciales entre los territorios forales y la normativa vigente en territorio de régimen común ${ }^{55}$.

Canarias, tradicionalmente ha gozado de un régimen económicofiscal peculiar, y así fue recogido en la Disposición Adicional Tercera de la $\mathrm{CE}^{56}$, al exigir un informe previo de la Comunidad Autónoma para la modificación del régimen tributario. No siendo óbice la singularidad del fenómeno insular, que le ha permitido dotarse de una serie de gravámenes como el Impuesto General Indirecto Canario, el Arbitrio sobre Importaciones y Entregas de Mercancías en Canarias, y el Impuesto Especial de la Comunidad Autónoma de Canarias sobres Combustibles derivados del Petróleo, lo cierto es que los mismos no constituyen una ampliación del poder tributario de la Comunidad,

${ }^{55}$ La STS de 9 de diciembre de 2004, entiende que la regulación en materia de prescripción en los territorios forales, por lo menos en cuanto al plazo de prescripción se refiere, debe ser idéntica a la establecida en territorio de régimen común al entender...que el plazo de prescripción forma parte del concepto de prescripción, y por ende, la obligatoria adecuación en cuanto a terminología y conceptos a la Ley General Tributaria a que obliga el artículo 7 del Convenio Económico con la Comunidad Foral de Navarra, implica la necesidad de tener el mismo plazo de prescripción. Curiosamente, el propio Tribunal Supremo entiende que, siendo el plazo de prescripción una parte inherente del concepto de la prescripción, y por ende, obligado en cuanto a su adecuación para la Comunidad Foral de Navarra, no forma parte del mismo el momento de inicio del cómputo de la prescripción. ALONSO ARCE, I.: "Una sentencia inoportuna y desafortunada», Actualidad Jurídica Aranzadi, número 673, 16 de junio de 2005, página 6, BIB 2005\1122; En dicha STS se indica en relación al rango de ley de las normas preautonómicas navarras, que ese hecho no supone ningún problema ni reparo desde el punto de vista del rango normativo de las disposiciones forales. El propio Tribunal recuerda que los Territorios Históricos de la Comunidad Autónoma del País Vasco, Álava, Bizkaia y Gipuzkoa, siguen produciendo a través de sus Juntas Generales normas con rango formal reglamentario pero que regulan materias sometidas a principio de reserva de ley, sin problemas de este sentido; Al examinar la relación de impuestos que integran el actual sistema tributario español se habrá observado una especie de duplicidad de impuestos en algunas zonas del territorio, en concreto, en Navarra y los territorios históricos del País Vasco (Álava, Guipúzcoa y Vizcaya), y es que en estos territorios no están vigentes todos los impuestos españoles comunes, sino otros paralelos de regulación, muchas veces, idéntica a la de aquellos comunes, pero con su propia promulgación y autonomía normativa y con sujetos activos distintos del Estado, que son el Gobierno o Diputación Foral de Navarra y las Diputaciones Forales de Álava, Guipúzcoa y Vizcaya. GARCÍA AÑOVEROS, J.; ESCRIBANO LÓPEZ, F.;CALERO GALLEGO, J.; PÉREZ ROYO, I. et alii: Manual del Sistema Tributario Español, Dykinson, Madrid, 1999, págs. 31 a 35.

${ }^{56}$ La DA 6 LOFCA atribuye a los órganos económico-administrativos de la Comunidad Autónoma de Canarias la competencia para conocer de las reclamaciones económico-administrativas que se susciten en materia de aplicación de los tributos y potestad sancionadora respecto del Impuesto General Indirecto Canario y del Arbitrio sobre Importación y Entrada de Mercancías en las Islas Canarias, integrantes del Régimen Económico y Fiscal de Canarias. 
sino la de unos tributos peculiares para la financiación de su Autonomía, de sus Cabildos y de sus Ayuntamientos ${ }^{57}$.

Ceuta y Melilla, conforme al artículo 144.6 de la CE, tienen un régimen de autogobierno y Estatutos de Autonomía, propios, aprobados por Leyes Orgánicas 2 y 1 de 1995, de 13 de marzo, respectivamente. Ello les dota de un régimen fiscal específico que se actualiza y garantiza mediante Ley del Estado. El sistema fiscal básico ${ }^{58}$ de dichos entes es el propio del régimen municipal, contando además con un Impuesto sobre la Producción, los Servicios y la Importación, regulado por Ley 8/1991, de 25 de marzo (objeto de la STJCE de 7 de diciembre de 1995, C-45/1994).

La función financiera, o conjunto de situaciones jurídicas en las que aparecen jurídicamente habilitados ciertos órganos de los entes públicos con las que se corresponden otras de los sujetos privados, para la ejecución de la actividad financiera en el plano de lo previamente establecido o aprobado por ley, constituye una parte de la función ejecutiva que, con arreglo al artículo 97 de la CE compete al Gobierno que la lleva a cabo por medio de la Administración Pública. En el ámbito del Estado el artículo 5.1 de la LGT afirma que «a los efectos de esta Ley, la Administración Tributaria estará integrada por los órganos y entidades de derecho público que desarrollen las funciones reguladas en sus títulos III, IV y V.», esto es, la aplicación de los tributos, la potestad sancionadora y la revisora en vía administrativa. En la esfera autonómica y local, predomina hoy, la unión, en una sola

${ }^{57}$ COLLADO YURRITA, M.A. y otros: Derecho Tributario...op. cit. págs. 118 y 119; Además tiene una serie de prerrogativas en la Disposición Adicional Décima de la Ley 20/1991, apartados 2 (sobre competencias normativas sobre la gestión, liquidación, recaudación e inspección del IGIC y del arbitrio Canario), $3^{\circ}$ (sobre competencia para contestar consultas tributarias relativas al IGIC y al Arbitrio Canario, salvo que afecte o tenga trascendencia en otros impuestos de titularidad estatal, y en todo caso, en las relativas a la localización del hecho imponible) y 4 (será reclamable en vía económicoadministrativa ante los órganos económicos-administrativos de la Comunidad Autónoma de Canarias la aplicación de los tributos y la imposición de sanciones tributarias que realice la comunidad autónoma respecto a los tributos derivados del Régimen Económico y Fiscal de Canarias), aunque, según la DA 11 de dicha Ley, las disposiciones interpretativas o aclaratorias a que se refiere el artículo 12 de la Ley General Tributaria y relativas al Impuesto General Indirecto Canario y al Arbitrio sobre Importaciones y Entregas de Mercancías en las islas Canarias se dictarán por el Ministro de Hacienda, a instancia o previo informe de la Comunidad Autónoma de Canarias.

${ }^{58}$ El IPSI no es más que un impuesto indirecto municipal que grava la producción, elaboración e importación de toda clase de bienes muebles corporales, prestación de servicios y entregas de bienes inmuebles situados en las ciudades de Ceuta y Melilla, correspondiendo a sus Ayuntamientos su gestión, recaudación, inspección. Por último, en dichas ciudades no se aplica el IVA, el Impuesto sobre el Alcohol y bebidas derivadas, cerveza, ni el especial sobre Hidrocarburos. GARCÍA AÑOVEROS, J. et alii: Manual ...op. cit., 1999, pág. 488. 
entidad, de la titularidad de todos los derechos y potestades y competencias que se dan en el plano de la exigencia y aplicación efectiva de las distintas facetas de la actividad financiera ${ }^{59}$.

En este orden de cosas, debemos indicar que, para algunos autores como Mestre García y Cervantes Sánchez-Rodrigo ${ }^{60}$, partiendo de la homogeneidad del ordenamiento tributario en materia sancionadora, concluyen que los preceptos de la LGT sobre infracciones y sanciones son de obligatoria ${ }^{61}$ aplicación incluso en el ámbito de los tributos propios de las Comunidades Autónomas. Sin embargo, otros, como Redondo Andreu ${ }^{62}$, reconocen facultad normativa a las Comunidades sobre sus tributos propios — no así en los cedidos ${ }^{63}$ - y admite que, en

${ }^{59}$ Sin perjuicio que en el ámbito autonómico lo afectante a gastos e ingresos competa a las diferentes Consejerías de Economía y Hacienda o a la de Hacienda, en exclusiva, creadas. CAZORLA PRIETO, L.M.: Derecho Financiero...op. cit. págs. 82,83 y 87 .

${ }^{60}$ MESTRE GARCÍA, E. y CERVANTES SÁNCHEZ-RODRIGO, C. J.: Guía de infracciones y sanciones tributarias, CISS, Valencia, 2005, págs. 21 y 22; FALCÓN Y TELLA, en materia de recargos autonómicos recaudados junto a tributos estatales, por el principio de coordinación, entiende que, aún competiendo a la Comunidad Autónoma su normación, al gestionarse de manera conjunta, por exigirlo la naturaleza del propio recargo, debe regirse por la normativa estatal, otra cosa podría dar lugar a superposición de normativas, de prescripción, sancionadora. FALCÓN Y TELLA, R.: Análisis crítico de jurisprudencia en materia de prescripción de las infracciones y sanciones tributarias, IEF, Madrid, núm.76, 1990, pág. 32.

${ }^{61}$ En diferentes normas propias de las Comunidades Autónomas relativas a tributos propios, se remiten a la aplicación del régimen sancionador establecido en la Ley General Tributaria. Así podemos citar a título de ejemplo el art. 10 de la Ley 9/2005, de la Comunidad Autónoma de la Región de Murcia...dispone que las infracciones tributarias en relación con los impuestos medioambientales se calificarán y sancionarán con arreglo a lo dispuesto en la LGT; Los arts. 30 y ss. de la Ley Balear $13 / 2005$, regulan el régimen sancionador de un impuesto propio de dicha Comunidad Autónoma, como es el Impuesto sobre circulación de vehículos de arrendamiento sin conductor; En la regulación de las tasas establecidas por la Comunidad Autónoma de Cantabria, en la Ley 6/2005, se establece que en todo lo relativo a la calificación de infracciones tributarias, así como en la determinación de las sanciones correspondientes, se estará a lo dispuesto en los arts. 178 y ss. LGT. AA.VV. (Coord. PELÁEZ MARTOS, J.M. ${ }^{\text {. }): ~ T o d o ~ p r o c e d i m i e n t o . . . o p . ~ c i t ., ~ 2006, ~ p a ́ g . ~} 994$.

${ }^{62}$ REDONDO ANDREU, I.: «La potestad sancionadora en materia tributaria y los sujetos infractores», en la obra colectiva dirigida por E. SIMÓN ACOSTA, Estudios sobre la nueva Ley General Tributaria. Homenaje a D. Pedro Luís Serrera Contreras, IEF, 2004, pág. 775.

${ }^{63}$ Las Comunidades Autónomas sólo pueden regular un impuesto cedido cuando así lo determine la normativa estatal...con el alcance y condiciones temporales y espaciales que se atribuyan. FERREIRO LAPATZA, J.J. y SARTORIO ALBALAT, S.: Curso de Derecho ...2004, op. cit. págs. 318-319; En igual sentido «En relación con los tributos cedidos, las CCAA no tienen competencia normativa en el régimen de infracciones y sanciones, ...» AA.VV. (Coord. PELÁEZ MARTOS, J.M. ${ }^{a}$.): Todo procedimiento...op. cit., 2006, pág. 993;En ese sentido el art. 45.1 de la Ley 22/2009, de 18 de diciembre, por la que se regula el sistema de financiación de las Comunidades 
la práctica, la que resultará aplicable será la LGT. Por último, otros, como Martínez Lago ${ }^{64}$, concretan que la LGT únicamente puede entrar en los ordenamientos tributarios propios de las Comunidades Autónomas a través de una decisión legislativa propia que la incorpore bien como derecho propio o como derecho supletorio. En opinión de Pérez Nieto y Baeza Díez-Portales ${ }^{65}$, la clave de la solución debe comenzar recordando la doctrina del Tribunal Constitucional, destacando su Sentencia 15/1992 en la que indica que sentencia que «las Comunidades Autónomas pueden adoptar normas administrativas sancionadoras cuando, teniendo competencia sobre la materia sustantiva de que se trate, tales disposiciones se acomoden a las garantías dispuestas en este ámbito del Derecho sancionador (art. 25.1 $\mathrm{CE}$ ), y no introduzcan divergencias irrazonables y desproporcionadas ${ }^{66}$

Autónomas de régimen común y Ciudades con Estatuto de Autonomía y se modifican determinadas normas tributarias regula «la titularidad de las competencias normativas y de aplicación de los tributos cuyo rendimiento se cede a las Comunidades Autónomas, de la potestad sancionadora, así como la revisión de los actos dictados en ejercicio de las competencias citadas, corresponde al Estado», sin perjuicio de las facultades de calificación e imposición de sanciones para los tributos cuya delegación de competencias en gestión tributaria se prevé en el art. 55.1.c) (Impuestos sobre el Patrimonio, sobre Sucesiones y Donaciones, sobre Transmisiones Patrimoniales y Actos Jurídicos Documentados, de los Tributos sobre el Juego, del Impuesto Especial sobre Determinados Medios de Transporte y del Impuesto sobre las Ventas Minoristas de Determinados Hidrocarburos); También el art. 19.2 LOFCA.

${ }^{64}$ MARTÍNEZ LAGO, M.A.: "Sobre principios de la potestad sancionadora en materia tributaria», $C T$, núm. 119, 2006, pág. 94.

${ }^{65}$ PÉREZ NIETO, R. y BAEZA DÍEZ-PORTALES, M.: Principios del Derecho Administrativo Sancionador Vol.I, CGPJ-Fundación Wellington, Madrid, 2008, págs. 257 a 259.

${ }^{66}$ Reviste especial importancia, en relación con la prescripción, la exigencia de respetar las competencias atribuidas al Estado por el art. 149.1.18, donde garantiza a los administrados un tratamiento común frente a las administraciones públicas. Con lo cual se asegura, en aras de la seguridad jurídica, un común denominador normativo, con posibilidades que cada una de ellas pueda establecer las peculiaridades que le convengan dentro siempre del marco competencial fijado en la Constitución y en los Estatutos de Autonomía. RUÍZ RESCALVO, M.P.: La prescripción tributaria y el delito fiscal, Dykinson-Univ. Rey Juan Carlos I, Madrid, 2004, pág. 32; También MARTÍN CÁCERES, A.F.: La prescripción del crédito tributario, IEF-Marcial Pons, Madrid, 1994, pág. 17; FALCÓN Y TELLA, R.: La prescripción en materia tributaria, La Ley, Madrid, 1992, pág. 58; La jurisprudencia del Tribunal Constitucional en base al principio de aplicación homogénea del sistema tributario (ha establecido)... la obligatoriedad de las Comunidades Autónomas de aplicar los preceptos de la LGT. AA.VV. (Coord. PELÁEZ MARTOS, J.M. . .): Todo procedimiento..op. cit., 2006, pág. 993.También la STSJ de Navarra de 9 de febrero de $1998\left(\mathrm{FJ}^{\circ}\right)$, cuando señala que las normas forales no pueden diferir sustantivamente de las estatales en materia de prescripción; La STC 14/1986, de 31 de enero, permitió en su FJ 12 que la interrupción de la prescripción de los derechos económicos de la Comunidad Autónoma Vasca exigiera el conocimiento formal del sujeto pasivo, aunque la notificación fuera defectuosa-cuando en el ámbito estatal se exigía que no lo fuera. 
al fin perseguido respecto del régimen jurídico aplicable en otras partes del territorio", así concluyen que, al ser competentes las Comunidades Autónomas en la materia sustantiva atinente a tributos propios, y de acuerdo con la doctrina del Tribunal Constitucional reseñada, tienen competencia sancionadora en cuanto a sus propios tributos ${ }^{67}$, además el procedimiento sancionador habrá de atenerse al procedimiento administrativo común (STC 87/1985, de 16 de julio)

Cordero García ${ }^{68}$ expresa que cabe plantearse si las CC AA pueden aprobar normas sancionadoras administrativas. Sobre este tema el artículo 149.1.1 de la CE indica que es competencia del Estado «la regulación de las condiciones básicas que garanticen la igualdad de todos los españoles en el ejercicio de sus derechos y en el cumplimiento de los deberes constitucionales». Este artículo ofrece apoyo para defender la necesidad de Ley estatal para la regulación de los delitos y las penas. Si se permitiese que las CC AA pudieran regular la materia penal, se diversificaría el panorama de los delitos y las penas, teniendo esto consecuencias muy negativas en el terreno de la igualdad. Esta misma interpretación podría haberse realizado en relación con las infracciones y sanciones administrativas, pero no ha sido así. Señala el $\mathrm{TC}^{69}$ que las CC AA pueden dictar normas sancionadoras siempre que tengan la competencia sobre la materia sustantiva de que se trate, y no introduzcan divergencias irrazonables y desproporcionadas al fin perseguido respecto del régimen jurídico aplicable en otras partes del territorio. Atendiendo al planteamiento expuesto, una sanción impuesta por una CC AA no menoscabaría necesariamente la competencia estatal establecida en el artículo 149.1.1, aunque podría hacerlo para el caso en que no se respetasen los límites anteriormente

${ }^{67}$ ANÍBARRO PÉREZ expone el problema entre los tributaristas, así PALAO TABOADA o MENÉNDEZ MORENO, estiman que la LGT no resulta aplicable a los tributos propios de las CCAA, por considerar que no existe título competencial en la CE sobre el que fundar la atribución por el Estado a su LGT ese pretendido ámbito de aplicación general. Otros autores (RAMALLO, SOLER ROCH, CALVO ORTEGA) defienden que sobre la base de uno o varios títulos competenciales, la actual LGT, en su art. 1.1, una parte de su contenido resulta de aplicación a todos los Entes públicos, inclusivo CCAA en sus tributos propios, incluyendo el régimen de infracciones y sanciones tributarias. También de este parecer fue la Comisión para el Estudio y propuesta de medidas para la reforma de la LGT. Así las SsTC 102/1985, de 4 de octubre, 48/1988, de 22 de marzo, 227/1988, de 29 de noviembre. ANÍBARRO PÉREZ, S. y SESMA SÁNCHEZ, B.: Infracciones y sanciones tributarias, Lex Nova, Valladolid, 2005, pág. 21.

${ }^{68}$ PARADA se muestra crítico con la realización de una interpretación distinta cuando el art. 149.1 afecta a la materia penal y cuando afecta a la sancionadora administrativa. CORDERO GARCÍA, J.A.: «La potestad sancionadora de la administración tributaria: principios reguladores», JT, núm.5, 2000.

${ }^{69}$ STC 87/1985, de 16 de julio. 
indicados. Parece razonable (SSTC 102/1985, de 4 de octubre y 227/1988, de 29 de noviembre, STC 87/1985, de 16 de julio, 48/1988, de 22 de marzo y 136/1991, de 20 de junio) que, sobre la base de la ordenación general del sistema sancionador por parte del Estado, las CC AA puedan establecer infracciones y sanciones en aras de la distribución territorial del poder, propia del Estado de las Autonomías.

En materia de infracciones y sanciones tributarias, resulta habitual que las CCAA, al regular sus propios tributos, se remitan a la $\mathrm{LGT}^{70}$, aunque consideramos que, en atención a la distribución del poder financiero que se deriva del Estado de las Autonomías, y a las características específicas que los tributos autonómicos pudieran presentar, resulta admisible que las CCAA puedan configurar el sistema de infracciones y sanciones de éstos, siempre dentro del marco de principios y normas establecidos con carácter general para todo el Estado. El artículo 19 de Ley Orgánica 8/1980, de 22 de septiembre, de Financiación de las Comunidades Autónomas (LOFCA), previene que [1]a aplicación de los tributos y la potestad sancionadora respecto a sus propios tributos corresponderá a la Comunidad Autónoma, la cual dispondrá de plenas atribuciones para la ejecución y organización de dichas tareas, sin perjuicio de la colaboración que pueda establecerse con la Administración Tributaria del Estado, especialmente cuando así lo exija la naturaleza del tributo. En caso de tributos cedidos, cada Comunidad Autónoma podrá asumir por delegación del Estado la aplicación de los tributos, la potestad sancionadora y la revisión, en su caso, de los mismos, sin perjuicio de la colaboración que pueda establecerse entre ambas Administraciones, todo ello de acuerdo con lo especificado en la Ley que fije el alcance y condiciones de la cesión, salvas en el Impuesto sobre la Renta de las Personas Físicas, en el Impuesto sobre el Valor Añadido, y en los Impuestos Especiales de Fabricación, en que la aplicación de los tributos, la potestad sancionadora y la derevisión, en su caso, de los demás tributos del Estado recaudados en cada Comunidad Autónoma, corresponderá a la Administración Tributaria del Estado, sin perjuicio de la delegación que aquélla pueda recibir de ésta y de la colaboración que pueda establecerse, especialmente cuando así lo exija la naturaleza del

${ }^{70}$ ZORNOZA PÉREZ, J. J.: El sistema de infracciones y sanciones tributarias. Los principios constitucionales del derecho sancionador, Civitas, Madrid, 1992, págs. 76 y 77; ANEIROS estima que el procedimiento diseñado en la LGT y en el RGRST será aplicable a los tributos cedidos, por cuanto estos tributos se remiten a las sanciones de la LGT. En cambio, en el ámbito de los tributos propios no parece existir inconveniente en una regulación propia, siempre que se respete el contenido mínimo del Capítulo IV del Título IV de la LGT. ANEIROS PEREIRA, J.: Las sanciones... op. cit. pág. 187. 
tributo. También el artículo 10. Dos de la LOFCA permite, [e]n caso de tributos cedidos, que cada Comunidad Autónoma pueda asumir, en los términos que establezca la Ley que regule la cesión de tributos, competencias normativas, entre cuya relación no se halla la normativa sancionadora. Más claro resulta el apartado primero del artículo 45 de la LO 22/2009, de 18 de diciembre, por la que se regula el sistema de financiación de las Comunidades Autónomas de régimen común y Ciudades con Estatuto de Autonomía y se modifican determinadas normas tributarias (LFCA) según el cual [l]a titularidad de las competencias normativas y de aplicación de los tributos cuyo rendimiento se cede a las Comunidades Autónomas, de la potestad sancionadora, así como la revisión de los actos dictados en ejercicio de las competencias citadas, corresponde al Estado. Únicamente en la gestión tributaria de los Impuestos sobre el Patrimonio, sobre Sucesiones y Donaciones, sobre Transmisiones Patrimoniales y Actos Jurídicos Documentados, de los Tributos sobre el Juego, del Impuesto Especial sobre Determinados Medios de Transporte y del Impuesto sobre las Ventas Minoristas de Determinados Hidrocarburos corresponderá a las Comunidades Autónomas la calificación de las infracciones y la imposición de sanciones tributarias (art. 55.1.c LFCA).

El régimen tributario y sancionador de las Haciendas Locales ${ }^{71} \mathrm{se}$ encuentra recogido, en su mayor parte, en el Real Decreto Legislativo 2/2004, de 5 de marzo, regulador del Texto Refundido de la Ley reguladora de las Haciendas Locales, cuyo artículo 11 se remite en materia de infracciones y sanciones al régimen de la Ley 58/2003, de 17 de diciembre, y ésta, en su Disposición Adicional cuarta recoge que «3. Las entidades locales, dentro del ámbito de sus competencias, podrán desarrollar lo dispuesto en esta ley mediante la aprobación de las correspondientes ordenanzas fiscales.»

${ }^{71}$ La Ley 7/1985, de 2 de abril, de Bases de Régimen Local, regula las Haciendas Locales en sus arts. 105 a 116 en su art. 135, prevé la posibilidad de creación de un órgano de gestión tributaria en los municipios de gran población, que ejercerá como propias las competencias que a la Administración Tributaria local le atribuye la legislación tributaria; el efecto expansivo del art.1 de la LGT se recoge en la STS de 20 de abril de 1988; La Hacienda General (art.149.1.14 CE) abarca específicamente la regulación Haciendas Locales (STC 233/2000). La Hacienda General abarca aquel sector del ordenamiento jurídico español integrado por la totalidad de los institutos jurídicos financieros en su vertiente estructural, exceptuando las normas elaboradas por entes distintos del Estado, en virtud de su autonomía financiera o su Derecho histórico. Pues bien, la regulación de las Haciendas Locales no forma parte de la Hacienda Autonómica, por que forma parte de la Hacienda General, con la excepción de lo que sucede en los territorios forales. PALAO TABOADA, C.: Comentario...op. cit., págs. 27 y 28 . 
Según Redondo Andreu ${ }^{72}$, las Entidades Locales, pese a que son autónomas para la gestión de sus propios intereses e implícitamente disponen de autonomía financiera ${ }^{73}$, y por el hecho que las Entidades Locales no dispongan de potestad legislativa ello veda la posibilidad de que establezcan infracciones y sanciones. Gonzalo y Gonzá$\mathrm{lez}^{74}$ opina que las especificaciones introducidas por los Entes Locales, ex art. 11 TRLHL, parece que son puramente organizativas, no existiendo habilitación para una Ordenanza Local específicamente referida a infracciones y sanciones. Por su parte, Martínez Lago ${ }^{75}$, considera que la nueva LGT representa una solución legal restrictiva para con las posibilidades de configuración infractora y de determinación de la sanción que cabría esperar de los plenarios de las Corporaciones Municipales, de acuerdo con la jurisprudencia del Tribunal Constitucional (así las SsTC 132/200176 o 25/2004) y del Tribunal

72 REDONDO ANDREU, I.: ...op. cit., pág. 775.

${ }^{73}$ FERREIRO LAPATZA, J.J.: Curso de Derecho...op. cit.2006, pág. 81.

${ }^{74}$ AA.VV. (Coord. GONZALO Y GONZÁLEZ, L.): Fiscalidad Autonómica y Local, Dykinson, Madrid, 2004, pág. 161.

${ }^{75}$ MARTÍNEZ LAGO, M.A.: «Sobre principios...», op. cit., pág. 94.

${ }^{76}$ Comentando esta sentencia, PULIDO QUEVEDO observa que verdadero nudo gordiano del recurso de amparo se encuentra en la consideración de si las Ordenanzas Municipales, son instrumentos normativos habilitados para tipificar infracciones e imponer sanciones. Para centrar la cuestión el TC parte de la doctrina sobre las Ordenanzas municipales sentada en la STC 233/1999 [Recurso de inconstitucionalidad c. Ley de Haciendas Locales], donde se expuso una concepción flexible de la reserva de ley en materia en relación con las tasas y precios públicos, reservándose un eslabón normativo a la Ordenanza municipal caracterizado por un ámbito de colaboración más intenso que el establecido para las relaciones LeyReglamento, en atención a que las Ordenanzas Municipales emanan de un órgano de carácter representativo, el Pleno del Ayuntamiento y que la garantía institucional de la autonomía local impide que la ley contenga un regulación agotadora de una materia - tributos locales- donde está claramente presente el interés local. Sin embargo dicha flexibilización de la aptitud de la Ordenanza fiscal para complementar la ley, con cierto aire de reglamento autónomo, como los Estatutos de las universidades, que se hace eco de algunas posiciones doctrinales, entre otros, en la doctrina ius administrativa, de las posiciones de PAREJO ALFONSO, no es trasladable al ámbito punitivo, allí donde se manifiesta el «ius puniendi» del Estado, en su vertiente sancionadora. Los argumentos que utiliza la STC 132/2001, son de un doble alcance. Por un lado, se dice, que el ámbito de la reserva de ley tributaria (art. 31.3 y $133 \mathrm{CE}$ ) y de la sancionadora, no son coextensas, o dicho de otro modo, son de orden diverso. Más estricta esta última, ya que su finalidad es la de garantizar la posición jurídica de cada ciudadano en relación con el poder punitivo del Estado. De otro, se señala, que la flexibilidad de la reserva establecida en la STC 233/1999, tenía como objeto de regulación un ámbito de la tributación local (tasas y precios público) donde se aprecia un componente sinalagmático muy relevante para la reserva de ley. Ahora bien, tras negar la identidad de las Ordenanzas o de las regulaciones municipales, derivadas del ámbito tributario o sancionador, la Sentencia da un salto o cabriola dialéctica y retranqueando el medio cuerpo expuesto en la doctrina anterior, señala que al igual que en el ámbito tributario local, en el

(C) UNED. Revista de Derecho UNED, núm. 22, 2018 
Supremo (por todas, STS de 29 de septiembre de 2003), y de la propia legislación de régimen local, destacando la Ley 57/2003, de 17 de diciembre, de medidas para la modernización del gobierno local, convirtiendo en mera fórmula retórica la previsión efectuada por el artículo 11 del Texto Refundido de la Ley de Hacienda Locales que contempla la facultad de especificación por medio de ordenanzas fiscales. Almenar Belenguer y Ripley Soria ${ }^{77}$, admiten que la

sancionador la «exigencia de ley para la tipificación de infracciones y sanciones ha de ser flexible» (sic). Pese a esta "contraditio in terminis», la sentencia parece apuntar un cierto ámbito o espacio normativo para la Ordenanza local en el ámbito punitivo. Ahora bien, precisa que dicho ámbito no es una patente de corso para excluir la reserva de ley y explicita - que la habilitación competencial contemplada en la LBRL - no orilla el eslabón de la reserva de ley, dado que el artículo 25.2 de la LBRL no contiene en sí la autorización para que cada municipio tipifique por completo y según su propio criterio las infracciones y sanciones administrativas de aquellas materias atribuidas a su competencia. Después de esta delimitación negativa del ámbito competencial municipal, avanza en lo que el TC considera como exigencia mínima del artículo 25.1 CE. En primer lugar, — declara- la ley debe fijar los criterios mínimos de antijuridicidad conforme a los cuales cada Ayuntamiento puede establecer tipos de infracciones. Precisa, además, que no se trata de fijación de tipos genéricos de infracciones luego completables por medio de Ordenanza municipal, sino de criterios que orienten y condicionen la valoración de cada municipio a la hora de establecer los tipos de infracción. En segundo lugar, por lo que se refiere a las sanciones, del artículo 25.1 CE deriva la exigencia al menos de que la ley reguladora de cada materia establezca las clases de sanciones que puedan establecer las Ordenanzas Municipales. Tampoco, vuelve a precisar, se exige aquí que la ley establezca una clase específica de sanción para cada grupo de ilícitos, sino una relación de las posibles sanciones que cada Ordenanza municipal puede predeterminar en función de la gravedad de los ilícitos administrativos que ella misma tipifica. Como puede observarse, bajo la flexibilización de la reserva de ley en materia sancionadora delimitada por el Fundamento 6 de la Sentencia en contradicción (aparente o no ) con lo señalado en el Fundamento 5 acerca de las diferencias entre la reserva de ley en materia tributaria local y sancionadora, se ha introducido una suerte de Caballo de Troya con una nueva mercancía relativa al ámbito normativo de la Ordenanza local en el ámbito punitivo, que más que flexibilizarla parece querer configurar un nuevo marco de relaciones entre la ley y la Ordenanza, y desde luego conlleva una nueva forma de legislación en la materia... Muchas dudas e interrogantes plantea esta sentencia, que resuelve de forma correcta el supuesto planteado, pero que introduce pese a su importancia y novedad, una "res dubiae», sobre el principio de legalidad en materia de infracciones y sanciones, donde la calificada flexibilización de la reserva de ley «ex» artículo 25.1CE conlleva problemas de bulto para la adecuada articulación, cuando proceda por razones competenciales, entre: Ley estatal, autonómica, reglamento y Ordenanza municipal. La delicada articulación de competencias entre Estado-municipio y CC AAmunicipio, el famoso carácter bifronte de nuestro régimen local, requiere de soluciones equilibradas y respetuosas del ámbito de actuación de cada poder territorial. PULIDO QUECEDO, M.: «Principio de legalidad administrativa y Ordenanzas Municipales: ¿un nuevo enfoque?», Repertorio Aranzadi del Tribunal Constitucional núm. 9, 2001, BIB 2001\957.

${ }^{77}$ ALMENAR BERENGUER, J. y RIPLEY SORIA, D. (Dir. SIMÓN ACOSTA, E.): La Nueva Ley General Tributaria, Aranzadi, 2004, pág. 1261. 
exigencia de ley para la tipificación de infracciones y sanciones ha de ser flexible en materias donde, por estar presente el interés local, existe un amplio campo para la regulación municipal y siempre que la regulación local la apruebe el Pleno del Ayuntamiento. En nuestra opinión ${ }^{78}$, la doctrina constitucional en materia local admite la colaboración normativa a través de Ordenanzas municipales, dentro de ciertos límites que incluyen la reserva al legislador, respecto de las infracciones, de la fijación de los criterios mínimos de antijuridicidad conforme a los cuales cada Ayuntamiento puede establecer tipos de infracciones, por lo que no se trata de la definición de tipos, ni de tipos genéricos, sino de criterios que orienten y condicionen la valoración de cada Municipio a la hora de establecer los tipos de infracción, y en materia de sanciones, la relación de una relación de las posibles sanciones que cada Ordenanza Municipal puede predeterminar en función de la gravedad de los ilícitos administrativos que ella misma tipifica. Ello debe ser cohonestado con la carencia de potestad legislativa local, cuya facultad de establecimiento y exigencia de tributos se realizará de acuerdo con la legislación del Estado reguladora de las Haciendas Locales y en las Leyes que dicten las Comunidades Autónomas, en los supuestos expresamente previstos en aquélla. En definitiva, mantenemos la posibilidad de especificar a través de Ordenanzas Fiscales el Derecho Administrativo Sancionador en materia tributaria.

Si bien los artículos reguladores de la prescripción tributaria son de aplicación general en la Hacienda Estatal y en su sistema impositivo, y por mor del art. 8.f) LGT, "se regulará en todo caso por ley, el establecimiento y modificación de los plazos de prescripción y caducidad, así como de las causas de interrupción del cómputo de los plazos de prescripción», sostenemos ${ }^{79}$ que no existe acuerdo, sin embargo sobre el alcance que en materia de prescripción tiene dicha reserva. Según Ruiz García, se trata sólo de una "preferencia de ley», aunque esta tesis no parece confirmada por la jurisprudencia, que ha declarado que la exigencia de ley en materia de prescripción encuentra su fundamento en el principio de reserva de ley tributaria recogido en los artículos 31.3 y 133.1 CE 1978 (STS 13.02.1984). Para Falcón y Tella ${ }^{80}$,

78 PÉREZ Nieto, R. y BAEZA DÍEZ-PORTAles, M.: Principios...op. cit. págs. 259 a 261; ANEIROS afirma que el art. 11 TRLHL permite establecer especificaciones en las Ordenanzas Locales, por lo que es posible encontrar un procedimiento similar al establecido con carácter general pero con ciertas matizaciones derivadas de la propia singularidad de los tributos locales. ANEIROS PEREIRA, J.: Las sanciones...op. cit. pág. 187.

${ }^{79}$ MARTÍN CÁCERES, A.F.:La prescripción...op . cit. págs. 15-16.

${ }^{80}$ FALCÓN Y TELLA, R.: La prescripción ...op. cit. pág. 53. 
la exigencia de ley, en este caso, no se basa en el principio de legalidad tributaria, dado que la prescripción no constituye uno de los elementos esenciales del hecho imponible reservados a la ley. Sin embargo, el principio de reserva de ley en relación con la normativa sobre la prescripción de las infracciones y sanciones tributarias, agrega a la exigencia de ley en la regulación de los plazos prescriptivos, el principio de legalidad que ha de informar todo el régimen jurídico de la potestad sancionadora de la Administración Pública, con arreglo al artículo $25 \mathrm{CE}$, lo que implica el mandato de que las infracciones tributarias aparezcan tipificadas con una norma con rango suficiente (STS 10.11.1986). En relación con ello entende$\operatorname{mos}^{81}$ que la posibilidad de extender por medio de disposiciones reglamentarias los plazos de prescripción ha de ser excluida, dado que supone una ampliación de la responsabilidad de los ciudadanos frente a la Administración que invade el ámbito de la reserva de ley formulada por el art. 53.1 CE.

Por su parte la Hacienda autonómica, conforme al art. 45.1 de la Ley 22/2009, de 18 de diciembre, por la que se regula el sistema de financiación de las Comunidades Autónomas de régimen común y Ciudades con Estatuto de Autonomía y se modifican determinadas normas tributarias "[l] a titularidad de las competencias normativas y de aplicación de los tributos cuyo rendimiento se cede a las Comunidades Autónomas, de la potestad sancionadora, así como la revisión de los actos dictados en ejercicio de las competencias citadas, corresponde al Estado». Sin embargo, tiene poder normativo sobre los tributos propios y recargos, por lo que, en principio, no existe ningún obstáculo para que sus respectivas Asambleas Legislativas establezcan normas específicas sobre la prescripción ${ }^{82}$. Más la aplicación general de las normas contenidas en la LGT vendrá exigida, tal como ha declarado el Tribunal Constitucional (STC 59/1986), por la garantía de un trato común a todos los ciudadanos frente a las Administraciones Públicas contempladas en el art. 149.1.18 $\mathrm{CE}^{83}$.

Por su parte, en el ámbito de las Haciendas Locales rige la LGT, que se aplica íntegramente a la Administración Local, sin perjuicio de las adaptaciones a la estructura organizativa y funcional local —que no alteraciones o variaciones materiales del régimen estatal- que puedan realizarse mediante Ordenanza ${ }^{84}$.

${ }^{81}$ GARCÍA DE ENTERRÍA, E. y FERNÁNDEZ, T.R.: Curso de Derecho Administrativo I y II, Civitas, Madrid, 2002, pág. 169.

${ }^{82}$ MARTÍN CÁCERES, A.F.:La prescripción ...op. cit. pág. 17.

${ }^{83}$ FALCÓN Y TELLA, R.: La prescripción...op. cit. págs. 57-58.

${ }^{84}$ Arts. 11 y 12 RD Lg. 2/2004, de 5 de marzo, TRLHL. 
En conclusión, las Administraciones Tributarias del Estado, de las Comunidades Autónomas y de las Entidades Locales, serán aquéllas respecto de las que podrá producirse la extinción de la responsabilidad derivada de la infracción tributaria, en cuanto responsables de la potestad punitiva que les ha otorgado el titular del poder tributario, pero únicamente las que disponen de poder legislativo, Estado y Comunidad Autónomas, tienen posibilidad de regular un marco jurídico regulador propio de infracciones y sanciones tributarias, así como la extinción responsabilidad derivada de esas infracciones y la de las sanciones.

\section{MARCO ORGÁNICO}

Antes de analizar cuál las causas por las que se extingue a la Administración la posibilidad de determinar la responsabilidad infractora tributaria es preciso determinar qué órganos ${ }^{85}$ tienen atribuida la potestad sancionadora en el ámbito tributario, para de este modo poder identificar a qué sujetos les está atribuida dicha competencia sancionadora, como también para hallar respecto de quien se ha extinguido la responsabilidad infractora tributaria ${ }^{86}$.

${ }^{85}$ Habrá que estar a la regulación del artículo 207 LGT que remite a la normativa con carácter supletorio al RGRST, y, en su defecto, con carácter supletorio a la Ley 30/1992, de 26 de noviembre y al Real Decreto 1398/1993, de 4 de agosto. Además para la Administración Local deberá considerarse el artículo 11 del RD Lg. 2/2004, de 5 de marzo, y para las Comunidades Autónomas el artículo 46 de la Ley 21/2001 (en materia de tributos cedidos). DÍEZ OCHOA, J.M.: Derecho Tributario Sancionador. Comentarios y casos prácticos, CEF, Madrid, 2005, pág. 492; La dualidad de procedimientos, la bifurcación funcional no se ha concretado en una dualidad orgánica. ESCRIBANO LÓPEZ, F.: «El procedimiento sancionador tributario en la Ley de Derechos y Garantías de los Contribuyentes y su desarrollo reglamentario». RCT-EF, núm. 196, 1999; También en esta materia el RGRST pretende ser novedosa, ya que en principio no parece que un reglamento sea el ámbito normativo adecuado para fijar normas de organización interna administrativa. No obstante, dadas las especiales garantías del administrado que deben existir en todo procedimiento sancionador, parece razonable que excepcionalmente sea el Reglamento el ámbito en el que esta materia sea desarrollada. MANCHO ROJO, R.: El régimen sancionador tributario y su aplicación a las haciendas locales, Fundación Asesores Locales, Málaga, 2005, pág. 149.

${ }^{86}$ Como es sabido, este ámbito constituye un atributo subjetivo condicionante de la validez de las actuaciones administrativas, resultando, pues, nada menos que nulos de pleno derecho los actos en materia tributaria que «hayan sido dictados por órgano manifiestamente incompetentes por razón de la materia o del territorio». HERMOSÍN, M.: Procedimiento... op . cit. pág. 135. GARBERÍ LLOBREGAT, J.(Dir.) et alii: Procedimiento sancionador...op. cit. T. II, pág. 1342; Y aunque otro cosa no sea posible ahora - por la duplicación de esfuerzos que produciría — quizás sea conveniente tener en cuenta, como horizonte, una separación más tajante tanto en el procedimiento como en el órgano competente para resolverlo, que ahora (art.211 LGT) puede ser el mismo que el que dictó o haya de dictar la liquidación o el superior jerárquico de quien haya propuesto su iniciación. FERREIRO LAPATZA, J.J.: Curso de Derecho ...2006, op. cit. pág. 563.

(C) UNED. Revista de Derecho UNED, núm. 22, 2018 
Hemos de diferenciar los órganos competentes ${ }^{87}$ según se trate de un procedimiento sancionador tributario realizado mediante tramitación separada ${ }^{88}$ o mediante tramitación conjunta ${ }^{89}$.

${ }^{87}$ Pueden verse al respecto PÉREZ ROYO, F.: Derecho Financiero y Tributario. Parte General, Civitas, Madrid, 2004, pág. 368; Si bien el artículo 134 LRJPAC [hoy art. 63.1 LPACAP] dispone que la imposición de sanciones administrativas se lleve a cabo mediante la tramitación del procedimiento legal o reglamentariamente establecido, así como que la resolución se adopte por un órgano diferente de aquel que se haya encargado de desarrollar las actuaciones instructoras, no creemos que la remisión del artículo 178 LGT a los principios generales de la potestad administrativa sancionadora sea suficiente para declarar vigente a esta última exigencia en el ámbito sancionador tributario. Debe tenerse en cuenta que el art. 134 LRJPAC no se integra en el capítulo que tiene por objeto los principios de la potestad sancionadora y sí en el que agrupa los principios del procedimiento sancionador, los cuales aparecen a primera vista excluidos de la remisión formal expresa de la LGT. GARCÍA BERRO, F.: Los procedimientos tributarios y derechos de los contribuyentes en la Nueva Ley General Tributaria, Marcial Pons, Madrid, 2004, pág. 178. En la actualidad el art. 63.1 LPACAP establece «Artículo 63. Especialidades en el inicio de los procedimientos de naturaleza sancionadora. 1. Los procedimientos de naturaleza sancionadora se iniciarán siempre de oficio por acuerdo del órgano competente y establecerán la debida separación entre la fase instructora y la sancionadora, que se encomendará a órganos distintos.»

${ }^{88}$ Como se desprende de estas disposiciones una vez mas se confirma que la identidad orgánica es la regla general, no solo en los supuestos de acta con acuerdo de renuncia a la tramitación separada. La separación entre los procedimiento de liquidación y sancionador, se reduce a la distinción de expedientes. El órgano que realiza las actuaciones inspectoras y el órgano que resuelve es el mismo. Esta identidad orgánica convierte a la separación del procedimiento punitivo en una separación meramente formal, incluso en la modalidad de la tramitación separada que se ha consagrado en la nueva Ley General Tributaria como un principio representativo. CAAMAÑO ANIDO, M. A.: «Separación de procedimientos - de liquidación y sancionador- sin separación de órganos», Impuestos, núms. 15 y 16, 2000, págs. 165 y ss. También LAMOCA afirma que «dado que la Ley 30/1992 no establece la necesidad de atribución de competencia específica para su tramitación a órganos distintos de los que siguieron el procedimiento de aplicación de los tributos, en la práctica tramitan los mismo órganos que lo hicieron en el procedimiento de aplicación de los tributos. LAMOCA PÉREZ, C.: Infracciones y sanciones tributarias. Análisis crítico del nuevo sistema de infracciones y sanciones en la Ley General Tributaria, CEF, Madrid, 2005, pág. 446.

${ }^{89}$ En primer término resulta llamativo la falta de sistemática y coherencia empleada para el establecimiento de la competencia administrativa en la resolución del procedimiento sancionador, ya que siendo la misma de enorme trascendencia en la validez de los actos administrativos, ni siquiera se le ha dedicado un artículo específico en la Ley General Tributaria. Trayectoria que parece haber seguido el Reglamento General del Régimen Sancionador Tributario, pues el tratamiento poco metódico que le otorga a este aspecto se encuentra disperso en varios preceptos de la norma reglamentaria. HERMOSÍN, M.: Procedimiento Sancionador...op. cit. pág. 142. GARBERÍ LLOBREGAT, J.(Dir.) et alii: Procedimiento sancionador...op . cit. T. II, pág. 1162 . 


\subsection{Procedimiento sancionador tributario realizado mediante tramitación separada}

En primer lugar nos referiremos al procedimiento sancionador tributario tramitado de modo separado al de aplicación de los tributos, esto es, el ordinario o general.

\subsubsection{Competencia objetiva}

Según el párrafo primero del artículo 20 del Real Decreto 2063/2004, de 15 de octubre, por el que se aprueba el reglamento general del régimen sancionador tributario (RGRST), la atribución de las competencias en el procedimiento sancionador, y salvo que una disposición establezca expresamente otra cosa, será la misma que la del procedimiento de aplicación de los tributos del que derive ${ }^{90}$. Dicho precepto consagra como regla general la identidad orgánica entre el órgano competente para liquidar y el órgano competente para proponer la sanción o sancionar, o entre el que haya instruido un procedimiento de gestión y quien asuma la instrucción del procedimiento sancionador subsiguiente ${ }^{91}$.

Sin embargo, el artículo $208.1^{\circ}$ de la Ley General Tributaria concreta que «el procedimiento sancionador en materia tributaria se tramitará de forma separada a los de aplicación de los tributos regulados en el título III de esta ley (gestión, inspección y recaudación tributaria), salvo renuncia del obligado tributario, en cuyo caso se tramitará conjuntamente», aunque en los supuestos de actas con acuerdo y en aquellos otros en que el obligado tributario haya renunciado a la tramitación separada del procedimiento sancionador ${ }^{92}$, las

${ }^{90}$ LAMOCA se pregunta el caso de que no derive de ningún procedimiento, v.gr. casos de denuncia tributaria, en cuyo caso habría que acudir a la normativa específica de cada Administración tributaria. LAMOCA PÉREZ, C.: Infracciones... op. cit.. pág. 451.

${ }^{91}$ ANÍBARRO PÉREZ Y SESMA SÁNCHEZ en la obra colectiva del Profesor CALVO ORTEGA, R. (Dir.), TEJERIZO LÓPEZ, J.M. (coord.) et alii: Los nuevos reglamentos tributarios, Thomson-Civitas, Navarra, 2006, pág. 316; También la STSJ de Madrid de 25 de abril de $2008\left(\mathrm{FJ}^{\circ}\right.$ ) y la STS de 12 de abril de 2005.

${ }_{92}$ Con parecidos términos se expresa en el artículo 21 del RD 2063/2004, de 15 de octubre; Críticamente, ANEIROS advierte que «la regulación contenida en los arts. 208 a 212 de la LGT, debe señalarse que resulta una separación de procedimientos meramente aparente ya que, en la medida en que los órganos con competencias para la aplicación de los tributos son los que imponen las sanciones, la situación no difiere mucho de la que se venía produciendo antes de la entrada en vigor de la LDGC. ANEIROS PEREIRA, J.: Las sanciones...op. cit. pág. 185. 
cuestiones relativas a las infracciones se analizarán en el correspondiente procedimiento de aplicación de los tributos de acuerdo con la normativa reguladora del mismo, conforme se establezca reglamentariamente (art. $208.2^{\circ}$ LGT).

La cláusula general del reglamento sancionador tributario nos remite a la ambigua declaración dispuesta en el art. 83.4 LGT (competencia objetiva), según la cual será cada Administración tributaria la que determine singularmente su estructura administrativa para la aplicación de los tributos. En este sentido el artículo 59.1 ${ }^{\circ}$ del Real Decreto 1065/2007, de 27 de julio, por el que se aprueba el Reglamento General de las actuaciones y los procedimientos de gestión e inspección tributaria y de desarrollo de las normas comunes de los procedimientos de aplicación de los tributos (RGGI), preceptúa que «la competencia territorial en la aplicación de los tributos se atribuirá de acuerdo con lo previsto en el artículo 84 de la Ley 58/2003, de 17 de diciembre, General Tributaria», estableciendo, seguidamente, los efectos ${ }^{93}$ en relación con la competencia de los órganos adminis-

${ }^{93}$ Dichos efectos son: a) Las funciones de aplicación de los tributos, incluidas las relativas a obligaciones anteriores, se ejercerán a partir de ese momento por el órgano correspondiente al nuevo domicilio fiscal o por aquel que resulte destinatario del cambio de adscripción, respectivamente. b) Los procedimientos que se encuentren en curso de tramitación en el momento en que se produzca de manera efectiva el cambio de domicilio o de adscripción, serán continuados y finalizados por el nuevo órgano competente. A estos efectos se remitirán a dicho órgano los antecedentes que sean necesarios. No obstante, cuando se hubiera iniciado de oficio un procedimiento de aplicación de los tributos con anterioridad a la comunicación del nuevo domicilio, dicha comunicación surtirá efectos en relación con la competencia del órgano administrativo al mes siguiente de su presentación, salvo que durante dicho plazo la Administración tributaria inicie un procedimiento de comprobación de la procedencia del cambio de domicilio, en cuyo caso todos los procedimientos iniciados de oficio antes de la referida comunicación se continuarán y finalizarán por el órgano que los viniese tramitando en tanto no se resuelva el expediente de comprobación del cambio de domicilio. Lo anterior no impedirá que la Administración tributaria pueda iniciar en cualquier otro momento un procedimiento de comprobación del domicilio fiscal del obligado tributario. Lo dispuesto en el apartado b) anterior no será de aplicación en las actuaciones y procedimientos de inspección y de declaración de responsabilidad tributaria, en los que el domicilio fiscal determinante de la competencia del órgano actuante será el que correspondiese al inicio de las actuaciones y procedimientos, incluso respecto de obligaciones anteriores, sin que el cambio de domicilio fiscal o de adscripción altere la competencia del órgano actuante en cuanto a los procedimientos ya iniciados antes de la comunicación del cambio de domicilio o de adscripción. Esta competencia se mantendrá aun cuando las actuaciones hayan de proseguirse frente al sucesor o sucesores del obligado tributario. En el caso de obligados tributarios no residentes sin establecimiento permanente en España, será competente el órgano de la Administración tributaria en cuyo ámbito territorial tenga el domicilio el representante del obligado tributario, el responsable, el retenedor, el depositario 
trativos en los procedimientos de aplicación de los tributos de la comunicación de un cambio de domicilio fiscal ${ }^{94}$, en el ámbito de una misma Administración tributaria, siempre que dicho criterio sea el que determine la competencia del órgano, o el cambio de adscripción a otro órgano.

La competencia en el procedimiento sancionador ${ }^{95}$, por tanto, la ostentarán los órganos que, dentro de la estructura de cada Administración tributaria, a los que se otorgue tal atribución, de los cuales, si es que existe una pluralidad de los mismos con diferente ámbito territorial (como ocurre con la Administración tributaria del Estado y de la mayoría de las Comunidades Autónomas), la competencia se asumirá por aquel órgano inferior jerárquico en cuyo ámbito territorial radique el domicilio fiscal del obligado tributario presuntamente responsable de la comisión de la infracción administrativa.

En el ámbito de las competencias del Estado, la aplicación de los tributos y el ejercicio de la potestad sancionadora corresponde al Ministerio de Hacienda, en tanto no haya sido expresamente encomendada por ley a otro órgano o entidad de derecho publico (art. 5.2.1 LGT), como, por ejemplo, acontece en el caso de sanciones consistentes en la suspensión del ejercicio de profesiones oficiales, empleo o cargo publico, cuya imposición queda reservada al Consejo de Ministros [art. 211.5.a LGT]. En el marco del Ministerio de Hacienda, las tales competencias de aplicación de los tributos y sancionadoras corresponden, de conformidad con los términos previstos en su ley de creación, a la Agencia Estatal de Administración Tributaria (art. 5.2.2 LGT), creada por el art. 103 de la Ley 31/1990, de 27 de diciembre, para cuyo desarrollo habrá que estar a lo dispuesto en el Real Decreto

o el gestor de los bienes o derechos, o el pagador de las rentas al no residente, sin perjuicio de lo previsto en la normativa propia de cada tributo. Las normas de organización específica podrán establecer los términos en los que el personal encargado de la aplicación de los tributos pueda realizar actuaciones fuera del ámbito competencial del órgano del que dependan. En el ámbito de competencias del Estado, el Director General del Catastro y los directores de departamento de la Agencia Estatal de Administración Tributaria podrán modificar de forma motivada la competencia que resulte de los apartados anteriores (Art. 59. $2^{\circ}, 3^{\circ}, 4^{\circ}$, $5^{\circ}$ y $6^{\circ}$ RD $\left.1065 / 2007\right)$.

${ }^{94}$ Paradójico resulta que «no se haya regulado como interrupción justificada en el RGRST la duración del procedimiento de comprobación del domicilio fiscal». De forma expresa sólo se suspende por los motivos del artículo 24.4 RGRST, que remite a los del artículo 180 LGT. LAMOCA PÉREZ, C.: Infracciones...op. cit. pág. 452.

95 GARBERÍ LLOBREGAT, J.: Procedimiento Sancionador..op. cit. T.II, pág. 1343; No puede pretenderse que el instructor en un procedimiento administrativo sancionador, y menos aún el órgano llamado a resolver el expediente, goce de las mismas garantías que los órganos judiciales (STC 22/1990, de 15 de febrero). En igual sentido, ZORNOZA PÉREZ, J.J.: El sistema ...op. cit. pág. 288. 
424/2016, de 11 de noviembre, por el que se establece la estructura orgánica básica de los departamentos ministeriales ${ }^{96}$, cuya disposición final segunda del citado real decreto determina la necesidad de completar la organización de cada ministerio, adaptándola a su nueva estructura básica, mediante la promulgación de un real decreto de desarrollo, el Real Decreto 769/2017, de 28 de julio, por el que se desarrolla la estructura orgánica básica del Ministerio de Hacienda y Función Pública y se modifica el Real Decreto 424/2016, de 11 de noviembre, por el que se establece la estructura orgánica básica de los departamentos ministeriales. También habrá que tener en consideración la Orden de 2 de junio de 1994 por la que se desarrolla la estructura de la Agencia Estatal de Administración Tributaria, la Orden PRE/3581/2007, de 10 de diciembre ${ }^{97}$, por la que se establecen los

${ }^{96}$ Que establece la estructura orgánica básica del Ministerio de Hacienda y Administraciones Públicas hasta el nivel de Dirección General, al amparo de lo previsto en el artículo 59.1 de la Ley 40/2015, de 1 de octubre, de Régimen Jurídico del Sector Público (LRJSP).

${ }^{97}$ De su texto articulado merecen la consideración los siguientes preceptos y apartados: Artículo 4. Departamento de Gestión Tributaria. 1. Corresponden al Departamento de Gestión Tributaria, además de las atribuidas específicamente a su titular en el número 2 de este artículo, las siguientes funciones y competencias: ...p) La dirección, planificación y coordinación del ejercicio de la potestad sancionadora vinculada a las actuaciones y procedimientos de gestión tributaria, salvo las actuaciones relativas a los tributos o derechos encomendados a otras áreas funcionales, así como la vinculada a las actuaciones de inspección tributaria relativas a la aplicación de regímenes objetivos de tributación desarrolladas por las unidades que se determinen en la correspondiente resolución de la Presidencia de la Agencia. ....2. Corresponden al titular del Departamento de Gestión Tributaria las siguientes competencias: ...e) La iniciación del procedimiento sancionador para la imposición de sanciones no pecuniarias derivado de actuaciones de gestión tributaria y de actuaciones inspectoras en su ámbito de competencias...Artículo 5. Departamento de Inspección Financiera y Tributaria. 1. Corresponden al Departamento de Inspección Financiera y Tributaria, además de las atribuidas específicamente a su titular en el número 2 de este artículo, las siguientes funciones y competencias: a) La dirección, planificación y coordinación de la inspección tributaria, así como del ejercicio de la potestad sancionadora vinculada a la misma, salvo las actuaciones relativas a los tributos o derechos encomendados a otras áreas funcionales. e) El establecimiento de criterios generales para los órganos de inspección financiera y tributaria en materia de delito contra la Hacienda Pública. f) La dirección, planificación y coordinación de las actuaciones y procedimientos de gestión tributaria, del ejercicio de la potestad sancionadora vinculada a los mismos, así como la ejecución de los programas de devoluciones desarrollados por las unidades que se determinen en la correspondiente resolución de la Presidencia de la Agencia. ... s) La realización directa de actuaciones de obtención de información, la coordinación de las unidades especializadas en captación de información y las funciones de asistencia mutua internacional, así como el inicio, instrucción y resolución de los procedimientos sancionadores que se deriven de dichas actuaciones. ..... u) La realización directa de las actuaciones que integran el procedimiento inspector en los términos previstos en las correspondientes disposiciones y la iniciación, instrucción y resolución de los procedimientos sancionadores que deriven de estas actuaciones... 2. Corresponden al titular del 
departamentos de la Agencia Estatal de Administración Tributaria y se les atribuyen funciones y competencias y las Resoluciones de la Presidencia de la AEAT de fecha 24 de marzo de $1992^{98}$, de 20 de julio

Departamento de Inspección Financiera y Tributaria las siguientes competencias: ...b) La iniciación del procedimiento sancionador para la imposición de sanciones no pecuniarias derivado de actuaciones inspectoras y de actuaciones de gestión tributaria en su ámbito de competencia. c) Acordar la interposición de querella por la presunta comisión de delitos contra la Hacienda Pública en el ámbito de funciones y competencias del Departamento, en el marco del régimen reglamentario de asistencia jurídica a la Agencia. d) Acordar la formulación de denuncia por la posible comisión de delitos contra la Hacienda Pública en el curso de procedimientos o actuaciones del Departamento, conforme a lo que disponga la Dirección General de la Agencia... Artículo 6. Departamento de Recaudación. 1. Corresponden al Departamento de Recaudación, además de las atribuidas específicamente a su titular en el número 2 de este artículo, las siguientes funciones y competencias: ... d) La dirección, planificación y coordinación de las funciones de la Agencia en materia de cuentas restringidas de recaudación de tributos, así como la autorización, supervisión, control y régimen de ingresos de entidades colaboradoras y de las que, en su caso, presten el Servicio de Caja, ejerciendo, con relación a las entidades colaboradoras en la gestión recaudatoria, las siguientes funciones y competencias: ... 6. ${ }^{\circ}$ La iniciación de procedimientos sancionadores y la imposición de sanciones tributarias en los supuestos de incumplimientos de órdenes de embargo de cuentas cuando la entidad depositaria tenga la condición de colaboradora. ... o) La dirección, planificación y coordinación del ejercicio de la potestad sancionadora vinculada a la gestión recaudatoria.... Artículo 7. Departamento de Aduanas e Impuestos Especiales. 1. Corresponden al Departamento de Aduanas e Impuestos Especiales, además de las atribuidas específicamente a su titular en el número 2 de este artículo, las siguientes funciones y competencias: ... d) La dirección, planificación y coordinación de la gestión y, en su caso, de la intervención de los Impuestos Especiales con excepción de la gestión del Impuesto Especial sobre Determinados Medios de Transporte. Asimismo, en materia de gestión y control de los Impuestos Especiales, con excepción del Impuesto Especial sobre Determinados Medios de Transporte, le corresponden las siguientes: ... 7..$^{\circ}$ La autorización de las entidades que pueden emitir las tarjetas previstas en la normativa de impuestos especiales como medios de pago específicos y la gestión y control de la relación de los importes abonados a través de dichos medios de pagos, así como la tramitación de los expedientes sancionadores y de revocación que pudieran derivarse en relación con la actividad de estas entidades. ...1) La dirección, planificación y coordinación del ejercicio de la potestad sancionadora vinculada a las actuaciones y procedimientos del área de aduanas e Impuestos Especiales. ...2. Corresponden al titular del Departamento de Aduanas e Impuestos Especiales las siguientes competencias: ... b) La iniciación del procedimiento sancionador para la imposición de sanciones no pecuniarias derivado de actuaciones en materia de aduanas e Impuestos Especiales. c) Acordar la interposición de querella por la presunta comisión de delitos contra la Hacienda Pública o de contrabando en el ámbito de funciones y competencias del Departamento, en el marco del régimen de asistencia jurídica a la Agencia Tributaria. ... j) Ejercer todas las competencias atribuidas al Departamento en materia de gestión y control de los Impuestos Especiales, incluidas, en su caso, las de iniciación y resolución del procedimiento sancionador.

${ }^{98}$ Entre cuyos apartados relativos a la competencia sancionadora destacamos: Dos. Oficinas Nacionales. 1 Oficina Nacional de Investigación del Fraude... El inicio y la tramitación de los procedimientos sancionadores derivados de las actuaciones 
inspectoras desarrolladas por los Equipos integrados en el Equipo Central de Información y en las distintas Áreas de la Oficina Nacional de Investigación del Fraude corresponderán a los mismos. 2. La Oficina Nacional de Fiscalidad internacional... El inicio y la tramitación de los procedimientos sancionadores derivados de las actuaciones inspectoras desarrolladas por los Equipos integrados en la Oficina Nacional de Fiscalidad Internacional corresponderán a los mismos. Cuatro. Dependencias Regionales de Inspección. 1. Funciones. Asimismo, las Dependencias Regionales de Inspección de las Delegaciones Especiales de la Agencia Estatal de la Administración Tributaria, en relación con las personas o entidades a que se refiere el número 2.4 del apartado siguiente, tienen atribuida la función de tramitar y resolver los procedimientos sancionadores derivados del incumplimiento de las limitaciones a los pagos en efectivo, salvo que corresponda a otros órganos. 2. Ámbito de actuación. 2.4 La función consistente en tramitar y resolver los procedimientos sancionadores derivados del incumplimiento de las limitaciones a los pagos en efectivo señalada en el apartado anterior se extenderá a todas las personas o entidades, con domicilio fiscal en el ámbito de la respectiva Delegación Especial de la Agencia Tributaria, sobre los que la Delegación Central de Grandes Contribuyentes no ejerza su competencia. Asimismo, podrá extender su competencia al resto de las partes intervinientes en la operación objeto del procedimiento sancionador. 3 . Estructura y competencia territorial. 3.3 Competencia Territorial. 3.3.2 Las Dependencias Regionales de Inspección son competentes para realizar actuaciones de obtención de información, así como para ejercer la correspondiente potestad sancionadora en caso de incumplimiento, respecto a cualquier obligado tributario con independencia de su adscripción y de su domicilio fiscal, cuando sea necesario para realizar las funciones que tiene atribuidas. 4. Área de Inspección. 4.2.1 Estructura.-El Área de Inspección estará integrada por los Equipos y Unidades de Inspección que se estimen convenientes. Podrán constituirse, por acuerdo del Director del Departamento de Inspección Financiera y Tributaria y a propuesta del Delegado Especial afectado, Equipos de Inspección formados por el número de Técnicos de Hacienda que en cada caso se determine por el Jefe de la Dependencia Regional, cuya dirección corresponderá a un Inspector de Hacienda quién, por delegación del Inspector Jefe, podrá dictar los actos de liquidación e imponer las sanciones que procedan como consecuencia de las actuaciones realizadas por los miembros del Equipo. Cinco. Los Inspectores Jefes. 2. Corresponde a los Inspectores Jefes planificar, coordinar y controlar las actuaciones de los Equipos y Unidades de las correspondientes Dependencias inspectoras, en orden a lograr una adecuada utilización de los medios disponibles para la mayor eficacia de las actuaciones. Además, corresponde a los Inspectores Jefes ejercer las siguientes competencias: e) Autorizar el inicio de los expedientes sancionadores en aquellos casos en los que la normativa reglamentaria exija dicha autorización, y dictar los actos de imposición de sanción. h) Iniciar y resolver los procedimientos sancionadores derivados del incumplimiento de las limitaciones a los pagos en efectivo. Asimismo, les corresponderá designar al Jefe de Equipo, Jefe de Unidad o funcionario que deba instruir dichos procedimientos sancionadores. Ocho. Firma de documentos. Asignación de firma. 4. Otros documentos. La firma de los acuerdos de inicio y propuestas de resolución de los procedimientos sancionadores iniciados como consecuencia de un procedimiento de inspección corresponderá al Jefe de Equipo, Jefe de Unidad o funcionario que haya suscrito o vaya a suscribir las actas, conforme a lo dispuesto en los números 2 y 3 anteriores, siempre que el inicio y la tramitación corresponda al mismo Equipo o Unidad que haya desarrollado o esté desarrollando las actuaciones de comprobación o investigación. En otro caso, corresponderá la firma del acuerdo de inicio y la propuesta de resolución del expediente sancionador al Jefe del Equipo, Jefe de Unidad o funcionario que haya sido designado por el Inspector Jefe. En las Unidades de Gestión de Grandes Empresas de las 
de $1992^{99}$, de la Agencia Estatal de Administración Tributaria, sobre organización y atribución de funciones a la Inspección de los Tributos, en el ámbito de las competencias del Departamento de Aduanas e Impuestos Especiales, 19 de febrero de $2004^{100}$, relativa a la organiza-

Dependencias Regionales de Inspección, la firma de los acuerdos de inicio y las propuestas de resolución de los procedimientos sancionadores corresponderá al Jefe de dicha Unidad, al funcionario que haya desarrollado las actuaciones de las que trae causa la infracción o a aquel que haya sido designado por el Inspector Jefe. La firma de la propuesta de resolución de los procedimientos sancionadores derivados del incumplimiento de las limitaciones a los pagos en efectivo corresponderá al Jefe de Equipo, Jefe de Unidad o funcionario que haya sido designado como instructor por el Inspector Jefe. Nueve. Entrega del expediente por los actuarios. 1. Las actas, las propuestas de imposición de sanción y las diligencias, acompañadas de todos sus antecedentes, debidamente fijados, ordenados y foliados, serán entregados por el funcionario, Equipo o Unidad a la unidad administrativa encargada de su tramitación. 2. Cuando las actas, las propuestas de imposición de sanción o diligencias se hayan formalizado en un lugar situado fuera del ámbito territorial de la Delegación de la Agencia Tributaria donde se halle la sede del Equipo o Unidad actuante de la Inspección de los Tributos, podrá servir como unidad administrativa la de la Delegación de la Agencia Tributaria en cuyo ámbito territorial se hayan formalizado aquéllas. Cuando las actas, las propuestas de imposición de sanción o las diligencias se hayan formalizado en un lugar situado en una de las islas Baleares o Canarias, en la cual no se halle la sede de la correspondiente Delegación de la Agencia Tributaria, podrá servir como unidad administrativa la que corresponda de la Administración de la Agencia Tributaria que hubiere en la isla y en cuyo ámbito se hubiesen formalizado aquéllas. [Once ter]. Disposición adicional cuarta. Los Delegados Especiales de la Agencia Tributaria serán los competentes para resolver los recursos de alzada contra los acuerdos de resolución de los procedimientos sancionadores derivados del incumplimiento de las limitaciones a los pagos en efectivo.

${ }^{99}$ De la que reseñamos el apartado [c] uarto. Inspectores Jefe. 2. Corresponde a los Inspectores Jefes, en particular, ejercer las siguientes competencias en el ámbito del RGGI: e) Autorizar el inicio de los expedientes sancionadores en aquellos casos en los que la normativa reglamentaria exija dicha autorización, y dictar los actos de imposición de sanción.

${ }^{100}$ Remarcamos los siguientes apartados: Quinto. Las Dependencias Regionales de Gestión Tributaria. 1. ${ }^{\circ}$ Funciones.-Corresponden a las Dependencias Regionales de Gestión Tributaria, respecto a los obligados tributarios con domicilio fiscal en el ámbito territorial de la respectiva Delegación Especial, las siguientes funciones y competencias que no se encuentren atribuidas a ningún otro órgano de Gestión Tributaria: e) El inicio, la tramitación y la resolución de los procedimientos sancionadores derivados de las actuaciones y procedimientos incluidos en las letras anteriores. $4 .^{\circ}$ Desarrollo de la estructura orgánica de la Dependencia Regional de Gestión Tributaria: 1. Las unidades administrativas que componen la Dependencia Regional de Gestión Tributaria, así como sus funciones, serán las que se establecen a continuación: D) Área, Servicio o Sección Regional Ejecutiva de Gestión Tributaria.-El Área, Servicio o Sección Regional Ejecutiva de Gestión Tributaria ejercerá sus funciones en todo el territorio de la Delegación Especial a través de las Unidades, Servicios o Secciones de Gestión de Beneficios Fiscales y Procedimientos Especiales, de Gestión y Comprobación de no residentes, de Gestión de Exportadores y otros operadores económicos y de Gestión Tributaria. D.2) Gestión y Comprobación de no residentes.-La Unidad, Servicio o Sección de Gestión y 
ción y atribución de Funciones en el ámbito de competencias del Departamento de Gestión Tributaria, de 21 de septiembre de 2004, de la Presidencia de la Agencia Estatal de Administración Tributaria, por la que se establece la estructura y organización territorial de la Agencia Estatal de Administración Tributaria, de 26 de diciembre de $2005^{101}$ y

Comprobación de no residentes podrá ejercer en todo el territorio de la Delegación Especial las siguientes competencias: b) La tramitación y propuesta de resolución de los expedientes sancionadores por las infracciones cometidas por estos contribuyentes.D.3) Gestión de Exportadores y otros Operadores Económicos.-La Unidad, Servicio o Sección de Gestión de Exportadores y otros Operadores Económicos asume la gestión y control tributario integral de los contribuyentes incluidos en el Registro de Exportadores y Otros Operadores Económicos o en la Cuenta Corriente Tributaria, con domicilio fiscal en el ámbito de la Delegación Especial. En particular ejerce las siguientes competencias: d) La tramitación y propuesta de resolución de los expedientes sancionadores por las infracciones cometidas por estos contribuyentes. D.4) Gestión Tributaria.-1. Corresponden a la Unidad, Servicio o Sección de Gestión Tributaria las siguientes competencias, en tanto no estén atribuidas a otros Órganos: c) La tramitación y propuesta de resolución de los expedientes de sanciones tributarias graves y la tramitación y propuesta de resolución de las simples, así como la propuesta de liquidación de intereses y recargos, cuando no estén expresamente atribuidas a otras Dependencias. 2. La organización y funciones de la Unidad, Servicio o Sección de Gestión Tributaria serán las siguientes: A) Servicio o Sección de Gestión Tributaria General: Este Servicio o Sección podrá tener, como máximo, las siguientes secciones u oficinas, con las competencias que se señalan: f) Sección de Procedimiento Sancionador: Le corresponde el inicio, tramitación y propuesta de resolución de los expedientes de imposición de sanciones por infracciones tributarias en vía de gestión tributaria, así como de intereses y recargos. Serán órganos competentes para iniciar el procedimiento sancionador en el ámbito de la Gestión Tributaria y en defecto de la Sección antes señalada en la letra f), el Jefe de la Oficina de Liquidación o, en su defecto, el Jefe de Servicio o Sección de Gestión Tributaria General. B) Unidad de Módulos: B.1) La Unidad de Módulos realizará la gestión y el control integral de los contribuyentes en régimen de estimación objetiva del Impuesto sobre la Renta de las Personas Físicas y de los regímenes especiales simplificado, de la agricultura, ganadería y pesca y del recargo de equivalencia, del Impuesto sobre el Valor Añadido. Dichas actuaciones comprenderán igualmente las tareas de información y asistencia referidas a dichos contribuyentes

En particular, tendrá las siguientes funciones: Control de incumplimientos con aplicación del procedimiento de gestión o inspección, según corresponda, incluida la tramitación de los expedientes de recargos, intereses, sanciones y recursos relacionados con la aplicación de los citados regímenes. D) Servicio o Sección de Verificación y Control: Corresponderá a este Servicio o Sección: Además de las propuestas de liquidación que consideren oportunas en cada caso, les corresponde iniciar, tramitar y proponer la resolución de los expedientes de imposición de sanciones por infracciones tributarias en vía de gestión tributaria, así como de intereses y recargos, en relación con los expedientes tramitados por estas mismas Unidades. Disposición adicional sexta. Los Delegados Especiales serán los competentes para resolver los recursos de alzada contra las resoluciones de los procedimientos sancionadores derivados del incumplimiento de las limitaciones a los pagos en efectivo dictadas por los órganos de ellos dependientes.

${ }^{101}$ De la que subrayamos los apartados: Segundo. Funciones y competencias de la Delegación Central de Grandes Contribuyentes. 1. La Delegación Central de Grandes 
Contribuyentes ejercerá, dentro de su ámbito de actuación, las competencias y funciones propias de la Agencia Tributaria para la aplicación del sistema tributario estatal y el aduanero y para el ejercicio de la potestad sancionadora, salvo que se atribuyan expresamente a otros órganos de la Agencia, la gestión recaudatoria de los demás recursos de naturaleza pública que corresponda a la Agencia conforme a la normativa vigente, así como cualquier otra competencia y función que le atribuya la normativa legal, reglamentaria y demás disposiciones que sean de aplicación. Tercero. Ámbito de actuación de la Delegación Central de Grandes Contribuyentes. 3. Desde el momento en el que se notifique la adscripción a los obligados tributarios indicados en los números anteriores, la Delegación Central de Grandes Contribuyentes ejercerá sus competencias sobre dichos obligados respecto a cualquier concepto impositivo y período no prescrito. Del mismo modo, desde el momento en que se les notifique el fin de la adscripción, cesará la competencia de la Delegación Central sobre dichos obligados tributarios. Cuando de conformidad con lo dispuesto en el artículo 59.6 del Reglamento general de las actuaciones y los procedimientos de gestión e inspección tributaria y de desarrollo de las normas comunes de los procedimientos de aplicación de los tributos o en el artículo 20.3 del Reglamento general del régimen sancionador tributario, se acuerde, a propuesta del titular de la Delegación Central, atribuir la competencia a la Delegación que corresponda por el cambio de adscripción realizado, se notificará al obligado tributario y se comunicará a la Delegación a la que estaba adscrito hasta ese momento. 4. Los órganos de la Delegación Central de Grandes Contribuyentes son competentes para realizar actuaciones de obtención de información, así como para ejercer la correspondiente potestad sancionadora en caso de incumplimiento, respecto de obligados tributarios no adscritos a la misma, cuando sea necesario para realizar las funciones que tiene atribuidas. Las Delegaciones Especiales de la Agencia Tributaria serán competentes para realizar actuaciones de obtención de información, así como para ejercer la correspondiente potestad sancionadora en caso de incumplimiento, respecto de obligados tributarios adscritos a la Delegación Central que tengan su domicilio fiscal o la sucursal, oficina o local que haya realizado las operaciones objeto del requerimiento en sus respectivos ámbitos territoriales, cuando sea necesario para realizar las funciones que tienen atribuidas. Sexto. Dependencia de Control Tributario y Aduanero. 2. Funciones y competencias. La Dependencia de Control Tributario y Aduanero tendrá atribuidas, dentro del ámbito de actuación de la Delegación Central de Grandes Contribuyentes, las funciones de aplicación de los tributos que integran el sistema tributario estatal y el aduanero cuya competencia corresponde a la Agencia Tributaria, a través de las actuaciones y procedimientos de inspección, así como de los procedimientos de verificación de datos, comprobación de valores, comprobación limitada y demás actuaciones de comprobación establecidas por la normativa vigente, teniendo la consideración de órgano con atribuciones propias de la inspección de los tributos.... También le corresponde el inicio, la tramitación y la resolución de los procedimientos sancionadores que se deriven de las actuaciones y procedimientos indicados en el primer párrafo de este número y de los procedimientos de declaración de responsabilidad cuando ésta tenga lugar antes de la finalización del período voluntario de pago y derive de liquidaciones dictadas por esta Dependencia, así como la ejecución de los acuerdos resultantes de los procedimientos amistosos en materia de imposición directa cuando el obligado tributario esté adscrito a la Delegación Central de Grandes Contribuyentes.... Corresponde a los Inspectores Jefes el ejercicio de las siguientes funciones y competencias: e) Autorizar el inicio de los expedientes sancionadores en aquellos casos en los que la normativa reglamentaria exija dicha autorización, y dictar los actos de imposición de sanción. 3. Equipos Nacionales de Inspección. Las actuaciones de comprobación e investigación atribuidas a la Dependencia de Control Tributario y Aduanero serán desarrolladas por Equipos Nacionales de Inspección, sin perjuicio de la realización por dichos Equipos de las demás actuaciones inspectoras establecidas en la normativa vigente, así como el inicio y la instrucción de los procedimientos 
la de 22 de enero de $2013^{102}$, de la Presidencia de la Agencia Estatal de la Administración Tributaria, sobre organización y atribución de competencias en el área de recaudación.

sancionadores que se deriven de las actuaciones y procedimientos indicados en el número 2 de este apartado y el inicio y tramitación de los procedimientos para declarar la responsabilidad cuando la competencia para declarar dicha responsabilidad corresponda al órgano competente para dictar la liquidación. 5. Unidad de Control Tributario y Aduanero.-Esta Unidad desarrollará preferentemente los procedimientos de verificación de datos, comprobación limitada y demás actuaciones de comprobación establecidas por la normativa vigente competencia de la Dependencia de Control Tributario y Aduanero, así como procedimientos de inspección de carácter parcial y los procedimientos sancionadores que se deriven de las actuaciones anteriores. Además de practicar las liquidaciones que procedan en cada caso, corresponde a esta Unidad tramitar y, en su caso, resolver los expedientes de imposición de sanciones por infracciones tributarias, así como de intereses y recargos, en relación con los expedientes tramitados por la Unidad. La Unidad de Control Tributario y Aduanero, dirigida por su titular, con la asistencia de uno o varios Adjuntos, estará integrada por los funcionarios que en cada momento se determinen por el titular de la Dependencia o sus Adjuntos. Corresponderá a los inspectores integrados en esta Unidad, con excepción de su titular, la suscripción de las actas que proceda extender por la misma. Asimismo, podrán realizar la instrucción de los procedimientos sancionadores que se deriven de las actuaciones que se desarrollen por la Unidad. Séptimo. Dependencia de Asistencia y Servicios Tributarios. 2. Funciones y competencias. La Dependencia de Asistencia y Servicios Tributarios tendrá atribuidas, en el ámbito de actuación de la Delegación Central de Grandes Contribuyentes, las funciones de aplicación de los tributos cuya competencia corresponde a la Agencia Tributaria, a través de las actuaciones y procedimientos de gestión tributaria y de recaudación. Asimismo le corresponderá el inicio, la tramitación y la resolución de los procedimientos sancionadores que se deriven de aquellas actuaciones y procedimientos. e) Dictar los siguientes actos y acuerdos: 2. Las resoluciones de imposición de sanciones cuya instrucción hayan realizado las unidades y equipos de la Dependencia, salvo que resulte competente otro órgano. 3. Unidades de Gestión. Las actuaciones y procedimientos de gestión tributaria atribuidos a la Dependencia de Asistencia y Servicios Tributarios serán desarrollados, con carácter general, por las Unidades de Gestión. Las Unidades de Gestión, dirigidas por Jefes de Unidad, estarán integradas por los funcionarios que en cada momento se determinen por el titular de la Dependencia o sus Adjuntos. Los Jefes de estas Unidades podrán ejercer las funciones y competencias de gestión tributaria y de ejercicio de la potestad sancionadora relacionadas en el número 2 de este apartado respecto a los obligados tributarios que el titular de la Dependencia les asigne. Asimismo, ejercerán las siguientes funciones y competencias: 4. Equipos Nacionales de Recaudación. Las actuaciones de gestión recaudatoria atribuidas a la Dependencia de Asistencia y Servicios Tributarios serán desarrolladas, con carácter general, por los Equipos Nacionales de Recaudación. Los Equipos Nacionales de Recaudación, dirigidos por Jefes de Equipo, estarán integrados por los funcionarios que en cada momento se determinen por el titular de la Dependencia, sus Adjuntos o los Inspectores Coordinadores. Los Jefes de los Equipos Nacionales de Recaudación tendrán, en el ámbito de actuación de la Delegación Central de Grandes Contribuyentes, las siguientes funciones y competencias: h) Realizar los actos de instrucción de los procedimientos sancionadores que le sean encomendados por el titular de la Dependencia y elevar la propuesta de resolución de dicho procedimiento.

${ }^{102}$ De la que conviene dejar trascrito: Tercero. Órganos territoriales de recaudación. 3. Además, el titular de la Dependencia Regional de Recaudación será competente para: 22) Acordar la imposición de sanciones tributarias, en aquellos expedientes 
Por lo que atañe a las Comunidades Autónomas y las entidades locales, estas ejercerán las competencias relativas a la aplicación de los tributos y a la potestad sancionadora a través de los órganos previstos en la normativa que resulte aplicable según su sistema de fuentes (art. 5.3 LGT). Sobre las Haciendas locales debemos estar a lo dispuesto en el Título VIII de la Ley 7/1985, de 2 abril, Reguladora de las Bases de Régimen Local, mientras que en relación con las Comunidades Autónomas resultaran aplicables las disposiciones previstas en sus respectivas leyes de Gobierno y Administración.

\subsubsection{Competencia Territorial}

El art. $20.1^{\circ}$ del RD 2063/2004 se remite a la un tanto más precisa manifestación del art. 84 LGT (competencia territorial), a cuyo tenor la competencia en la aplicación de los tributos se atribuirá al órgano que se determine por cada Administración tributaria mediante disposición que deberá ser objeto de publicación en el boletín oficial correspondiente, si bien, en defecto de disposición expresa, dicha competencia territorial habrá de ostentarla el órgano funcional inferior en cuyo ámbito territorial radique el domicilio fiscal del obligado tributario ${ }^{103}$.

cuya instrucción hayan realizado los órganos de recaudación de la Delegación Especial, salvo que resulte competente otro órgano. 7. Competencias de los Técnicos Jefes de Grupo Regional de Recaudación. - Los Técnicos Jefes de Grupo Regional de Recaudación ejercerán las competencias atribuidas a los Técnicos de Hacienda en esta Resolución en los supuestos de ausencia de tales técnicos en la estructura organizativa de su Grupo Regional de Recaudación, y cuando los obligados tributarios no resulten asignados a Técnicos de Hacienda del Grupo Regional de Recaudación sino que su gestión se realice directamente por el Técnico Jefe. Además, ejercerán, respecto de los expedientes que resulten asignados a su Grupo Regional de Recaudación, las siguientes competencias: 10) Realizar los actos de instrucción de los procedimientos sancionadores que le sean encomendados por el titular de la Dependencia Regional de Recaudación y elevar la propuesta de resolución de dicho procedimiento, salvo que el Grupo Regional de Recaudación esté integrado en un Equipo Regional de Recaudación, en cuyo caso la propuesta será competencia del titular del Equipo. Cuarto. Competencias en materia de recaudación de los titulares de las Delegaciones Especiales, Delegaciones de la Agencia Tributaria y Administraciones. 3. Competencias de los titulares de las Administraciones de la Agencia Tributaria y de los Inspectores Coordinadores en materia de recaudación. Los titulares de las Administraciones, ejercerán respecto de las personas o entidades asignadas a los Equipos o Grupos Regionales de Recaudación de la Administración de que se trate las siguientes competencias: e) Acordar la imposición de sanciones tributarias, en aquellos expedientes cuya instrucción hayan realizado los órganos de recaudación de la Administración.

${ }^{103}$ Ampliamente viene regulado el domicilio fiscal en el artículo 48 de la LGT. DÍEZ OCHOA, J.M.:Derecho Tributario...op. cit. pág. 498. 
Esa regla general de competencia y dado que el criterio atributivo de la competencia en materia de infracciones y sanciones tributarias es el domicilio fiscal del presunto responsable, hace que resulte necesario cuestionarse qué sucede respecto de dicha competencia cuando se produce un cambio en dicho domicilio una vez concluso el procedimiento de aplicación de los tributos ${ }^{104}$ que determine la procedencia del expediente sancionador. En este sentido, el art. 20 del RD 2063/2004 dispone las dos posibilidades. En el supuesto de procedimientos sancionadores que no se inicien como consecuencia de un procedimiento de inspección o recaudación (excepción hecha de los procedimientos de gestión en materia de aduanas o de impuestos especiales), la comunicación a la Administración tributaria del cambio de domicilio fiscal determinará que la competencia para el inicio o continuación del procedimiento sancionador corresponda al órgano competente según el nuevo domicilio. Dicho cambio producirá este efecto en el plazo de un mes desde la presentación de la comunicación. No obstante, si durante ese plazo la Administración tributaria inicia un procedimiento de comprobación de la procedencia del cambio de domicilio, no se alterará la competencia del órgano en tanto no se resuelva el procedimiento (art. 20.2.b) RGRST) ${ }^{105}$. La norma reglamentaria no ha dejado previsto el supuesto de que tal circunstancia se hubiera producido antes de la conclusión del procedimiento de aplicación de los tributos. En este caso, el cambio de domicilio o de adscripción producirá efectos sobre el órgano competente para la resolución del procedimiento de aplicación de los tributos, por lo que esa alteración conllevará la de la competencia del órgano competente para instruir y resolver el expediente sancionador.

${ }^{104}$ Según el parecer de ANÍBARRO PÉREZ Y SESMA SÁNCHEZ para que opere esta alteración de la competencia sancionadora es necesario que la comunicación del cambio de domicilio se haya producido con posterioridad a la terminación del procedimiento que corresponda. VV.AA obra colectiva del Profesor CALVO ORTEGA, R. (Dir.), TEJERIZO LÓPEZ, J.M. (coord.) et alii: Los nuevos reglamentos...op. cit. págs. 275 y 276.

${ }^{105}$ Así el artículo $48.3^{\circ}$ LGT «Los obligados tributarios deberán comunicar su domicilio fiscal y el cambio del mismo a la Administración tributaria que corresponda, en la forma y en los términos que se establezcan reglamentariamente. El cambio de domicilio fiscal no producirá efectos frente a la Administración tributaria hasta que se cumpla con dicho deber de comunicación, pero ello no impedirá que, conforme a lo establecido reglamentariamente, los procedimientos que se hayan iniciado de oficio antes de la comunicación de dicho cambio, puedan continuar tramitándose por el órgano correspondiente al domicilio inicial, siempre que las notificaciones derivadas de dichos procedimientos se realicen de acuerdo con lo previsto en el artículo 110 de esta ley». DÍEZ OCHOA, J.M.:Derecho Tributario... op. cit. págs. 499 a 501. 
En el supuesto de procedimientos sancionadores iniciados como consecuencia de un procedimiento de inspección o de recaudación, el domicilio fiscal determinante de la competencia del órgano administrativo será el que el obligado tributario tuviera al inicio de las actuaciones inspectoras o recaudadoras, sin que el posterior cambio de domicilio fiscal o de adscripción altere dicha competencia ${ }^{106}$, salvo acuerdo expreso del director de departamento competente (art.20.3 RGRST) ${ }^{107}$.

El RGRST no aclara dos extremos. De un lado, qué sucede con los cambios de domicilio tramitados de oficio por la propia Administración, no a instancia del interesado, por lo opinamos ${ }^{108}$ que la rectificación del domicilio por parte de la Administración traerá consigo el cambio de adscripción del obligado tributario a otra unidad o dependencia que será la competente en materia sancionadora con efectos a partir del dictado del acuerdo correspondiente. De otro lado, nos preguntamos qué sucede si el cambio de domicilio se produce antes de la terminación del procedimiento que corresponda, considerando que será de aplicación la regla general del artículo, con lo que el cambio de domicilio notificado arrastrará consigo la competencia del órgano ${ }^{109}$.

\subsubsection{Competencia por cambio de adscripción ${ }^{110}$ o de domicilio del obligado tributario}

Por otro lado, y con independencia de cual sea el domicilio fiscal del presunto responsable, también contempla el Reglamento sancio-

${ }^{106}$ La STS de 28.01.2013 establece que «...la falta de competencia sobrevenida, pero que en modo alguno puede calificarse de manifiesta en los términos que exige el $\operatorname{art}^{\mathrm{o}}$ 62.1..b) de la Ley 30/1992, sino que posee relevancia invalidante en cuanto del citado vicio se produjera indefensión de la parte o se hubiera impedido al acto alcanzar su fin...»(FJ $\left.3^{\circ}\right)$.

${ }^{107}$ Nos planteamos ¿qué sucede cuando no devienen del procedimiento de inspección strictu sensu sino de una comprobación limitada efectuada por los servicios de inspección? Podemos concluir, que cuando el artículo 20.3 RGRST se refiere a «actuaciones inspectoras» lo realiza en sentido lato y no estricto, por lo que podríamos entender que el supuesto también engloba a las actuaciones de inspección y comprobación. LAMOCA PÉREZ, C.: Infracciones...op. cit. pág. 453.

${ }^{108}$ GÓMEZ-MOURELO CASTEDO, S.: El nuevo régimen sancionador tributario comentado, La Ley, Madrid, 2004, pág. 289.

${ }^{109}$ ANÍBARRO PÉREZ Y SESMA SÁNCHEZ en la obra colectiva del Profesor CALVO ORTEGA, R. (Dir.), TEJERIZO LÓPEZ, J.M. (coord.):Los nuevos reglamentos...op. cit. pág. 320 .

${ }^{110}$ Viene determinada básicamente por el volumen de ventas del obligado tributario a efectos del IVA. También es posible por otros motivos mediante acuerdo del órgano competente. MESTRE GARCİA, E. y CERVANTES SÁNCHEZ-RODRIGO, C. J.: Guía de infracciones...op. cit. pág. 249. 
nador tributario la eventualidad consistente en el cambio de adscripción - del sujeto a quien se considera presunto responsable de la comisión de un ilícito tributario- de una unidad o dependencia administrativa competente por razón del territorio a otra diferente (v.gr. de grandes contribuyentes, de investigación del fraude). En tal caso, dicho cambio de adscripción determinará que la competencia para la iniciación o continuación del procedimiento sancionador corresponda al órgano competente según la nueva adscripción a partir de la fecha en que se dicte ${ }^{111} \mathrm{el}$ acuerdo de cambio de adscripción (art. 20.2.a) RGRST) ${ }^{112}$.

En aquellos casos en que se haya producido un cambio de domicilio durante la tramitación del procedimiento de inspección, el órgano competente para iniciar el procedimiento sancionador será el equipo o unidad que hubiera desarrollado la actuación de comprobación e investigación y el órgano competente para sancionar es el que debe dictar la liquidación que ponga término al procedimiento de inspección, o sea, el Inspector-Jefe del órgano en el que se han desarrollado las actuaciones ${ }^{113}$.

Sin embargo, en el supuesto de procedimientos sancionadores iniciados como consecuencia de un procedimiento de inspección o de recaudación, el domicilio fiscal determinante de la competencia del órgano administrativo - para iniciar o continuar el procedimiento sancionador - será el que el obligado tributario tuviera al inicio de las actuaciones inspectoras o recaudadoras, sin que el posterior cam-

${ }^{111}$ La falta de notificación al sujeto del cambio de adscripción no supondrá la nulidad del procedimiento si no ha provocado indefensión. ANÍBARRO PÉREZ Y SESMA SÁNCHEZ en la obra colectiva del Profesor CALVO ORTEGA, R. (Dir.), TEJERIZO LÓPEZ, J.M. (coord.):Los nuevos reglamentos...op. cit. pág. 321.

${ }^{112}$ Así para el caso de procedimientos de gestión, salvo de gestión aduanera o de Impuestos Especiales, el cambio de domicilio posterior a la terminación del procedimiento de gestión puede alterar la competencia. Sin embargo este cambio no es automático, sino que se produce después del transcurso del plazo de un mes de la presentación de la comunicación del cambio de domicilio. Durante ese plazo la Administración puede iniciar un procedimiento de comprobación de la procedencia del cambio de domicilio, de forma que la competencia del órgano del domicilio original no se altera en tanto no se resuelva dicho procedimiento. Nada obsta, también, a que el órgano administrativo del anterior domicilio finalice el procedimiento sancionador antes de que transcurra el citado plazo del mes. MESTRE GARCÍA, E. y CERVANTES SÁNCHEZ-RODRIGO, C. J.: Guía de infracciones...op. cit. pág. 248.

113 PELÁEZ advierte esta circunstancia y la pone en relación con lo previsto en el art. 25 RGRST, precepto según el cual el órgano competente para resolver el procedimiento sancionador [en caso de tramitación separada de procedimientos sancionadores iniciados como consecuencia de un procedimiento de inspección] será el inspector-jefe. AA.VV. (Coord. PELÁEZ MARTOS, J.M. ${ }^{\mathrm{a}}$ ): Todo procedimiento Tributario 2007-2008, CISS, Valencia, 2007, pág. 1185. 
bio de domicilio fiscal o de adscripción altere dicha competencia, salvo acuerdo expreso del director de departamento competente (art. 20.3 RGRST) ${ }^{114}$.

\subsubsection{Competencia para iniciar el procedimiento sancionador}

Con carácter general, será órgano competente para iniciar el procedimiento sancionador el que se determine en la norma de organización aplicable a los órganos con competencia sancionadora, y, en defecto de norma expresa, será órgano competente el que tenga atribuida la competencia para su resolución (art. 22.2 RGRST) ${ }^{115}$. En el caso de que el procedimiento sancionador a instruir traiga causa de una resolución de un procedimiento de gestión, y ante el silencio absoluto del texto reglamentario, y por aplicación de la cláusula residual indicada, el órgano competente para iniciarlos, instruirlos y resolverlos sería el órgano de gestión que hubiera dictado el acto de liquidación tributaria, con lo que se quiebra el principio esencial rector de estos procedimientos sancionadores sobre la conveniencia de diferenciar el órgano que inicia, instruye y resuelve el procedimiento ${ }^{116}$.

${ }^{114}$ En consecuencia, salvo acuerdo del Director del departamento de Inspección Financiera y Tributaria de la AEAT, dichas circunstancias no alterarán la competencia territorial del órgano de la inspección para la imposición de la sanción cuando esta corresponda al órgano de liquidación. DÍEZ OCHOA, J.M.: Derecho Tributario...op. cit. págs. 520 a 521; La competencia del órgano que inició el procedimiento de inspección no supone privar al cambio de domicilio correctamente comunicado a la Administración de sus demás efectos legales, en concreto los relativos al lugar procedente para practicar notificaciones. A ello parece referirse para los procedimientos de aplicación de los tributos, el art. 48.3 con referencia al art. 110 de la LGT. En consecuencia, el cambio de domicilio correctamente realizado tiene efectos para determinar el lugar de localización del interesado a efectos de notificaciones. MESTRE GARCÍA, E. y CERVANTES SÁNCHEZ-RODRIGO, C. J.: Guía de infracciones...op. cit. pág. 249.

${ }^{115}$ Este artículo plantea un problema si se pone en relación con el supuesto que Garberí LLobregat denomina procedimiento sancionador tributario ordinario abreviado (op. cit. 2005, T.I, pág. 1145) regulado en el art. $210.5^{\circ}$ LGT y art. $23.6^{\circ}$ RGRST. Considerado que en defecto de normativa competencial, es competente para iniciar el órgano que lo sea para resolver, y dado que en este caso se prescinde del trámite de instrucción, aunque preservando el trámite de audiencia, y se pasa del acto de incoación al de resolución, hemos de considerar que se puede llegar a producir la identidad entre órgano instructor (subsumido en la figura del acuerdo de iniciación con propuesta de resolución) y el órgano resolutor; Como regla general establece que el órgano competente para iniciar el procedimiento sea el mismo que es competente para resolver aunque con importante excepciones. MESTRE GARCÍA, E. y CERVANTES SÁNCHEZ-RODRIGO, C. J.: Guía de infracciones...op. cit., pág. 251.

${ }^{116}$ ESEVERRI MARTÍNEZ, E.: Derecho Tributario. Parte General, Tirant lo Blanch, Valencia, 2011, pág. 465; Esa identidad orgánica existe plenamente cuando no existe

(C) UNED. Revista de Derecho UNED, núm. 22, 2018 
Si el expediente sancionador se inicia como consecuencia de un procedimiento de inspección, será de aplicación lo dispuesto en el art. 25.1 RGRST. Si se trata de actuaciones inspectoras distintas de las que integran el procedimiento de inspección ${ }^{117}$, será competente para iniciar el procedimiento sancionador el equipo o unidad que haya desarrollado las actuaciones ${ }^{118}$ de que trae su causa la infracción (art. 22.3

una tramitación separada del procedimiento sancionador (arts. 26 y 27). CALDERÓN GONZÁLEZ, J.M.: «El procedimiento sancionador en la nueva Ley 58/2003, de 17 de diciembre, General Tributaria, y sus Reglamentos de desarrollo. La interrupción de la acción administrativa para sancionar. Efectos del procedimiento tendente a la determinación de la deuda tributaria», Impuestos, núm. 2, Sección Doctrina, quincena del 16 al 31 Ene. 2009, Año XXV, Ref. D-552.

${ }^{117}$ En ese sentido el objeto del procedimiento de inspección se regula en el art. 145 LGT, y así «1. El procedimiento de inspección tendrá por objeto comprobar e investigar el adecuado cumplimiento de las obligaciones tributarias y en el mismo se procederá, en su caso, a la regularización de la situación tributaria del obligado mediante la práctica de una o varias liquidaciones.2.La comprobación tendrá por objeto los actos, elementos y valoraciones consignados por los obligados tributarios en sus declaraciones.3.La investigación tendrá por objeto descubrir la existencia, en su caso, de hechos con relevancia tributaria no declarados o declarados incorrectamente por los obligados tributarios». Así quedarían incardinadas en el concepto de actuaciones inspectoras distintas las funciones administrativas establecidas en el art. 141 LGT. Advierte LAMOCA que no existe un procedimiento de comprobación e investigación formal, si bien esto es el objeto del procedimiento de inspección según el artículo 145 LGT. LAMOCA PÉREZ, C.: Infracciones...op. cit. pág. 472. Tras el desarrollo reglamentario, el RGGI no son procedimiento de inspección el de verificación de datos, de comprobación de valores y comprobación limitada; Opina DÍEZ OCHOA que el art. 20.3.b) RGRST se refiere a aquellos procedimientos instruidos por los órganos de inspección al margen del procedimiento inspector, que, de acuerdo con lo establecido en el artículo 145 LGT tienen como objeto la comprobación e investigación del adecuado cumplimiento de las obligaciones tributarias. Serán ...expedientes sancionadores que deriven de procedimientos de comprobación limitada o de actuaciones de obtención de información realizadas de acuerdo con lo establecido en los artículos 93 y 94 LGT. DÍEZ OCHOA, J.M.: Derecho...op. cit. págs. 510 y 511.

${ }^{118}$ Según el artículo 166.1 ${ }^{\circ}$ del RD 1065/2007, de 27 de julio, «a efectos de lo dispuesto en este reglamento, se entiende por órganos de inspección tributaria los de carácter administrativo que ejerzan las funciones previstas en el artículo 141 de la Ley 58/2003, de 17 de diciembre, General Tributaria, así como aquellos otros que tengan atribuida dicha condición en las normas de organización específica»; Para ESCRIBANO la nota decisiva a los efectos de la iniciación será la propuesta que aparezca en el acta de inspección. ESCRIBANO LÓPEZ, F.: «El procedimiento sancionador tributario en la Ley de Derechos y Garantías de los Contribuyentes y su desarrollo reglamentario", $R C T-E F$, núm. 196, 1999, pág. 10; Sin embargo, otros autores diferencian entre la propuesta de inicio del procedimiento que corresponde al actuario que ha realizado el procedimiento de comprobación y el inicio propiamente dicho que se produciría por resolución del Inspector Jefe. MARTÍNEZ HORNERO, F.J.: «Idoneidad constitucional de la acción sancionadora de la Inspección de los Tributos», RCT-EF, núm. 226, 2002, pág. 52; MUÑóZ BAÑOS es el funcionario que instruye el expediente administrativo ordinario quien tiene competencias para iniciar el procedimiento sancionador ...debiendo estar 
RGRST $)^{119}$. En el supuesto del art. 25.1 RGRST en que el procedimiento sancionador se inicie como consecuencia de un procedimiento de inspección, entonces será competente para acordar dicha iniciación el equipo o unidad que hubiese desarrollado la actuación de comprobación o investigación ${ }^{120}$, salvo que el inspector-jefe designe otro diferente ${ }^{121}$. Cuando el inicio y la tramitación correspondan al mismo equipo o unidad que haya desarrollado o esté desarrollando las actuaciones de comprobación e investigación, el acuerdo de inicio podrá suscribirse por el jefe del equipo o unidad o por el funcionario que haya suscrito o vaya a suscribir las actas. En otro caso, la firma corresponderá al jefe de equipo o unidad o al funcionario que determine el inspector-jefe ${ }^{122}$.

debidamente autorizado por el Inspector Jefe para poder hacerlo. MUÑÓZ BAÑOS, C.: "Algunas reflexiones acerca del procedimiento sancionador tributario", RDFHP, núm. 258, 2000, pág. 950; ANEIROS opina que se trata de un supuesto de inicio del procedimiento por orden de un superior jerárquico, previa propuesta del actuario correspondiente puesto que este último nunca podrá iniciar el expediente por sí solo sin una orden de inicio. ANEIROS PEREIRA, J.: Las sanciones...op. cit. págs. 199 y 200;La norma no habla de órgano sino de equipo o unidad, por lo que parece acoger la tesis de que en el ámbito de la inspección sólo tiene la consideración de órgano administrativo la Dependencia de inspección o la Oficina Nacional correspondiente y no cada uno de los equipos o unidades que la integran. MESTRE GARCÍA, E. y CERVANTES SÁNCHEZ-RODRIGO, C. J.: Guía de infracciones...op. cit. pág. 254; Aunque el Inspector haya manifestado en el acta la ausencia de motivos para proceder a la apertura de expediente sancionador, el Inspector-Jefe puede ordenar la iniciación de expediente sancionador dentro del plazo de tres meses desde que se hubiese notificado la correspondiente notificación (STSJ La Rioja, 10.04.2001). AA.VV. (Coord. PELÁEZ MARTOS, J.M. ${ }^{\mathrm{a}}$.): Todo procedimiento..op. cit., 2007, pág. 1166.

${ }^{119}$ Alaban que se haya hecho desaparecer la mención al «funcionario que hubiera desarrollado la actuación».MARCOS CARDONA, M.: El procedimiento sancionador tributario, Iustel, Madrid, 2005, pág. 54. También MESTRE GARCÍA, E. y CERVANTES SÁNCHEZ-RODRIGO, C. J.:Guía de infracciones... op. cit. pág. 25.

${ }^{120}$ A juicio de ANÍBARRO PÉREZ y SESMA SÁNCHEZ si ha existido comunicación del cambio de domicilio por parte del sujeto, hay que advertir que las notificaciones deberán practicarse en el nuevo domicilio a pesar de que la competencia sancionadora resida en el órgano del domicilio inicial. ANÍBARRO PÉREZ Y SESMA SÁNCHEZ en la obra colectiva del Profesor CALVO ORTEGA, R. (Dir.), TEJERIZO LÓPEZ, J.M. (coord.):Los nuevos...op. cit. págs. 320 y 321; y ello pese a que el art. 110 LGT no establece ningún orden de prelación sobre el lugar donde debe notificarse. MESTRE GARCÍA, E. y CERVANTES SÁNCHEZ-RODRIGO, C. J.: Guía de infracciones...op. cit. pág. 249.

${ }^{121}$ Este precepto ... anula «de facto» la separación entre el procedimiento sancionador y el inspector. RICARDO HOYOS, J.:«El procedimiento sancionador tributario como procedimiento separado». QF, núm. 3, 2001.

${ }^{122}$ Apartado redactado según la redacción dada por el apartado uno de la disposición final primera del R.D. 1065/2007, de 27 de julio, por el que se aprueba el Reglamento General de las actuaciones y los procedimientos de gestión e inspección tributaria y de desarrollo de las normas comunes de los procedimientos de aplicación de los tributos («B.O.E.» 5 septiembre). 
En todo caso ${ }^{123}$, el inicio del procedimiento sancionador requiere autorización previa del inspector-jefe ${ }^{124}$, que podrá ser concedida en cualquier momento del procedimiento de comprobación e investigación o una vez finalizado este, antes del transcurso del plazo máximo establecido en el art. 209.2 de la LGT (art. 25.1 RGRST) ${ }^{125}$.

${ }^{123}$ Acabando así con aquella disquisición acerca de la interpretación del artículo 49.2 RGIT cuando establecía, en su letra j), que uno de los requisitos de las actas de inspección era que, en su caso, se hiciera constar la ausencia de motivos para proceder a la apertura del procedimiento sancionador, que a juicio de algunos este mecanismo parecía estar solo pensado para los supuestos en los que en el acta incoada existe una declaración contraria a la iniciación del expediente sancionador. ARGILÉS Y GARCÉS DE MARCILLA, J. L.: «Procedimiento Sancionador Tributario (1. parte)», $G F$, núms. 190 y 191, 2000, pág. 135.

${ }^{124} \mathrm{Sin}$ embargo, cuando un inspector-jefe hubiere realizado directamente las actuaciones de comprobación e investigación, no podrá dictar la correspondiente liquidación, reservándose tal potestad otro inspector-jefe determinado al efecto. MARTÍNEZ LAGO, M.A. y GARCÍA DE LA MORA, L.: Lecciones...op. cit. pág. 443; Para ANÍBARRO PÉREZ a pesar de la importancia que la norma reglamentaria concede a esta autorización y al momento de prestarla, desde la perspectiva del obligado tributario es un trámite superficial cuya omisión, consideramos, no tendría entidad suficiente - más allá de la disciplinaria interna- para invalidar el expediente sancionador por el simple hecho de que, amén de su fácil subsanación, en la generalidad de los casos no será conocida por el presunto infractor. ANÍBARRO PÉREZ, S. y SESMA SÁNCHEZ, B.: Infracciones...op. cit., 2005, pág. 219; también en la obra colectiva del Profesor CALVO ORTEGA, R. (Dir.), TEJERIZO LÓPEZ, J.M. (coord.):Los nuevos reglamentos ... op. cit. pág. 330, Según la SAN de 4 de noviembre de $2008\left(\mathrm{FJ}^{\circ}\right)$ «Entiende esta Sala que la ordenación del inicio del procedimiento sancionador es la fecha de inicio del procedimiento sancionador (en el caso del tramitación abreviada coincide con la de la propuesta de resolución del expediente sancionador conforme al artículo 34 del Real Decreto 1930/1998 ) y no la fecha de la autorización ya que la autorización del Inspector Jefe no puede calificarse como de una orden para la iniciación del mismo. La orden la da el órgano autorizado a través del acuerdo de iniciación del expediente (que no es competencia del superior sino del actuario). El hecho de que exista una autorización del Inspector Jefe al actuario para iniciar el expediente sancionador no obliga a este a iniciarlo ya que esa autorización no tiene efectos vinculantes por lo tanto hasta que no se acuerda el inicio del expediente no existe acuerdo u «orden» alguna para la iniciación del mismo. A esa conclusión llega esta sección sexta de esta Audiencia Nacional que señala en sentencia de 3 de marzo de 2.005 (recurso 482/02 ): "Para la Sala, la iniciación del expediente sancionador a que se refiere el artículo 49.2 j) RGIT es algo diferente a la autorización del Inspector-Jefe para iniciar dicho expediente. Aparte de que sólo el primero, esto es, el acuerdo de iniciación, se pone en conocimiento formal del sujeto pasivo, mientras que la autorización es una nota interna administrativa, la distinción entre ambos conceptos aparece nítida en el artículo 63 bis 2 RGIT, que separa claramente entre la autorización del Inspector Jefe y el Acuerdo para iniciar el procedimiento sancionador, que corresponde al funcionario, equipo o unidad que hubiera desarrollado las actuaciones inspectoras». Del mismo modo se pronuncia la sección cuarta en sentencia de 15 de junio de 2.005».

${ }^{125}$ Para CASANOVA CABALLERO esta situación no nos parece admisible, máxime si tenemos en cuenta que en ningún caso nos encontraríamos ante dos órganos diferentes, tal y como mandan los mencionados preceptos legales, sino ante dos funcionarios (Inspector actuario e Inspector jefe) de un mismo órgano, como es la Inspección de los tributos, entre los que existe una dependencia jerárquica. AA VV. [Coord. MANTERO 


\subsubsection{Competencia para instruir el procedimiento sancionador}

En lo relativo a la instrucción de los expedientes sancionadores, el art. 23.1 del RGRST atribuye la competencia administrativa, igualmente de manera genérica, al órgano que se determine en la normativa de organización que resulte aplicable ${ }^{126}$, norma que nada dice a propósito de la identificación de dicho órgano ${ }^{127}$. En caso de que el asunto instruido traiga causa de un procedimiento de gestión tributaria, sería el propio órgano de gestión tributaria que actuó comprobando la situación tributaria del obligado quien instruiría el procedimiento sancionador, siendo ése el mismo que inició el procedimiento sancionador.

Sin embargo, en los casos en que el procedimiento sancionador se haya iniciado como consecuencia de un procedimiento de inspección, la instrucción del procedimiento podrá encomendarse por el inspector-jefe al equipo o unidad competente para acordar el inicio o a otro equipo o unidad distinta, en función de las necesidades del servicio o de las circunstancias del caso. Cuando el inicio y la tramitación del procedimiento sancionador correspondan ${ }^{128}$ al mismo equipo o unidad que haya desarrollado o esté desarrollando las actuaciones de comprobación e investigación, la propuesta de resolución podrá suscribirse por el jefe del

SÁENZ, A. y JIMÉNEZ-REYNA RODRÍGUEZ, E.]: Ley General Tributaria, Antecedentes y comentarios, AEDAF y Asociación Española de Abogados Especialistas en Derecho Tributario, Madrid, 2005, pág. 882. Con esta identidad orgánica de nuevo nos encontramos ante un procedimiento sancionador tributario convertido en un solo apéndice del resto de procedimientos de aplicación de los tributos, — - se ha producido un cambio en la estructura de los procedimientos tributarios de connotaciones lampedusianas: todo ha cambiado para que todo siga igual. ALONSO FERNÁNDEZ, F., et alii: El Estatuto del Contribuyente, Madrid, Francis Lefebvre, Madrid, 1999, pág. 236.

${ }^{126}$ No obstante la separación funcional, la imparcialidad de la autoridad decisora sólo existirá si no ha efectuado actividad inquisitiva alguna contra el acusado. El instructor, al estar en contacto directo con el inculpado, para evitar prejuicios e impresiones a favor o en contra del acusado que influyan a la hora de sentenciar, no debe ser el órgano que resuelva...Si no hay independencia, sino jerarquía (STC 22/1990, de 15 de febrero), de nada sirve la distribución, no se consigue la imparcialidad. FUSTER ASENCIO, C.: El procedimiento...op. cit. págs. 151 y 152 (en su pág. 154 se enumeran sentencias del TEDH que corroboran su postura); también la SsTC 98/1990, de 24 de mayo, 138/1990, de 20 de junio, STS de 25 de junio de 1990; A favor que la traslación del ámbito penal no sea mimética al administrativo, siguiendo la corriente constitucional, GARBERÍ LLOBREGAT, J.(Dir.) et alii. El procedimiento administrativo sancionador, Tirant lo Blanch, Valencia, 1994, pág. 201; ZORNOZA PÉREZ, J.J.: El sistema ...op. cit. págs. 117 y 118.

127 ESEVERRI..., 2011, op. cit. pág. 466.

128 Por tanto podría darse una situación en la que el equipo o unidad fuera diferente del que inicia el expediente, y , además, que el equipo o unidad que instruya el expediente sea otro diferente al que efectuó el inicio del procedimiento sancionador. En estos casos, será necesario contar con la autorización del inspector-jefe para modificar la regla general de la competencia. 
equipo o unidad o por el funcionario que haya suscrito o vaya a suscribir las actas. En otro caso, la firma corresponderá al jefe de equipo o unidad o al funcionario que determine el inspector-jefe (art. 25.3 RGRST) ${ }^{129}$.

Es discutible ${ }^{130}$, a efectos de valorar la culpabilidad del sujeto pasivo, que sean unos mismos órganos los que practiquen la comprobación, instruyan la sanción y propongan la misma olleguen a sancionar, pues tienen formada una opinión subjetiva de la culpabilidad del sujeto pasivo. No obstante, el Tribunal Constitucional, en su Sentencia 22/1990, de 15 de febrero, ha considerado que a efectos de garantizar dicha competencia basta que intervengan, dado que se trata de la misma organización administrativa, unidades orgánicas diferentes. Por su parte, la Sala de lo Contencioso-Administrativo de la Audiencia Nacional, Sección Segunda, en Sentencia de 10 de mayo de 2004, recurso 269/2004, en actuaciones referidas a fechas posteriores a la entrada en vigor de la Ley 1/1998 y respecto a la alegación referida a que el Instructor de expediente sancionador y el Actuario que llevó a cabo las actuaciones de comprobación fueron la misma persona, declaraba: «...el artículo 34 de la Ley 1/1998 únicamente exigen que la imposición de sanciones se haga en expediente distinto e independiente del instruido para la comprobación e investigación de la situación tributaria del interesado y que se de audiencia al interesado, pero sin que en forma alguna se exija que las fases instructora y sancionadora estén encomendadas a órganos distintos; máxime teniendo en cuenta que, en cualquier caso, la resolución sancionadora ha sido adoptada por el Inspector Jefe, por lo que, en caso de que existiera el vicio denunciado (que no se aprecia), entraría en juego lo previsto en el artículo 67.3 de la Ley 30/1992, de 26 de noviembre, de Régimen Jurídico de las Administraciones Públicas y del Procedimiento Administrativo Común, sobre la convalidación del acto administrativo».

\subsection{Procedimiento sancionador tributario realizado mediante tramitación conjunta}

La identidad orgánica entre el órgano liquidador y el sancionador es máxima cuando no existe una tramitación separada del procedimiento sancionador ${ }^{131}$.

${ }^{129}$ Puesto que en el procedimiento sancionador no se exige la colaboración del obligado tributario, .... será difícil apreciar la comisión de la infracción tributaria tipificada en el artículo 203 LGT (resistencia, excusa o negativa) en el curso de dicho procedimiento. DÍEZ OCHOA, J.M.: Derecho Tributario...op. cit. pág. 515.

${ }^{130}$ CALDERÓN GONZÁLEZ, J.M.: «El procedimiento sancionador...»op. cit.

${ }^{131}$ ANÍBARRO PÉREZ Y SESMA SÁNCHEZ en la obra de CALVO ORTEGA, R. (Dir.), TEJERIZO LÓPEZ, J.M. (coord.):Los nuevos reglamentos...op. cit. pág. 316. 
2.2.1. En caso de que se inicie como consecuencia de un procedimiento inspector mediante acta con acuerdo

El procedimiento sancionador se entenderá iniciado con el acta con acuerdo que se extienda, en la que también se incluirá la propuesta de sanción que proceda y se hará constar expresamente la renuncia a la tramitación separada del procedimiento sancionador, así como la conformidad del interesado con las propuestas de regularización y de sanción que se formulen.

En este caso la competencia será la del órgano competente en el procedimiento de aplicación de los tributos de que dimane dicho procedimiento sancionador, según se le atribuya de acuerdo con lo previsto en el artículo 84 de la Ley 58/2003, de 17 de diciembre, General Tributaria y en el artículo 59 del RGGI, que establecen los criterios de atribución de competencia en el ámbito de las Administraciones tributarias $^{132}$.

2.2.2. En caso de que se inicie como consecuencia de renuncia a la tramitación separada

De conformidad con lo preceptuado en el párrafo primero del artículo 27 del Real Decreto 2063/2004, de 15 de octubre «cuando el interesado haya manifestado que renuncia a la tramitación separada del procedimiento sancionador, su inicio deberá notificarse y, a partir de ese momento, su tramitación se desarrollará de forma conjunta con el procedimiento de aplicación de los tributos, y será de aplicación para ambos procedimientos la regulación establecida en la Ley 58/2003, de 17 de diciembre, General Tributaria, y en su normativa de desarrollo para el correspondiente procedimiento de aplicación de los tributos, incluida la relativa a los plazos y a los efectos de su incumplimiento" aunque cada procedimiento deberá finalizar con un acto resolutorio distinto ${ }^{133}$.

En este caso la competencia será la del órgano competente en el procedimiento de aplicación de los tributos de que dimane dicho procedimiento sancionador, según se le atribuya de acuerdo con lo previsto en el artículo 84 de la Ley 58/2003, de 17 de diciembre, General Tributaria.

132 DÍEZ OCHOA, J.M.:Derecho Tributario...op. cit. pág. 548.

${ }^{133}$ Un buen desarrollo de dicho procedimiento puede verse en DÍEZ OCHOA, J.M.:Derecho...op. cit. págs. 541 a 547. 


\subsection{Competencia para la terminación}

Para concluir con el presente apartado hay que aludir a la competencia para acordar la terminación del procedimiento sancionador, mediante el dictado de la correspondiente resolución absolutoria o condenatoria, competencia que, a diferencia de las relativas a la iniciación e instrucción de aquel, aparece directamente reseñada en la propia LGT, cuyo párrafo quinto del artículo 211 de la Ley General Tributaria dispone que son órganos competentes para la imposición de sanciones:

a) El Consejo de Ministros, si consisten en la suspensión del ejercicio de profesiones oficiales, empleo o cargo público.

b) El Ministro de Hacienda, el órgano equivalente de las comunidades autónomas, el órgano competente de las entidades locales u órganos en quienes deleguen, cuando consistan en la pérdida del derecho a aplicar beneficios o incentivos fiscales cuya concesión le corresponda o que sean de directa aplicación por los obligados tributarios, o de la posibilidad de obtener subvenciones o ayudas públicas o en la prohibición para contratar con la Administración pública correspondiente ${ }^{134}$.

c) El órgano competente para el reconocimiento del beneficio o incentivo fiscal, cuando consistan en la pérdida del derecho a aplicar el mismo, salvo lo dispuesto en el párrafo anterior.

d) El órgano competente para liquidar o el órgano superior inmediato de la unidad administrativa que ha propuesto el inicio del procedimiento sancionador.

${ }^{134}$ Si tenemos en cuenta lo dispuesto en el artículo 186.2.a) de la Ley 58/2003, al tipificar las sanciones no pecuniarias, en caso de beneficios fiscales aplicables mediante concesión o acuerdo administrativo (carácter rogado), serán el Ministro de Hacienda o el órgano equivalente de las comunidades autónomas, el órgano competente de las entidades locales u órganos en quienes deleguen, los competentes para la imposición de la sanción no pecuniaria. Por el contrario, cuando se trate de beneficios fiscales aplicables directamente por el obligado tributario en la correspondiente declaración o autoliquidación, la pérdida de dicho beneficio no tendrá la consideración de sanción no pecuniaria. En estos casos, la regularización de la situación tributaria del obligado tributario conllevará la exigencia de la deuda tributaria correspondiente al beneficio fiscal aplicado directamente por el obligado tributario en su declaración o autoliquidación... siendo, por tanto, el órgano liquidador el competente para imponer la sanción por la infracción tributaria cometida. DÍEZ OCHOA, J.M.:Derecho Tributario...op. cit. págs. 495 y 496. 
Adicionalmente, el art. 25.7 del RD 2063/2004 añade a la anterior regulación que, en los procedimientos sancionadores iniciados como consecuencia de un procedimiento de inspección, el órgano competente para dictar el acto resolutorio será el inspector-jefe. Sin embargo, cuando provenga de un procedimiento de gestión tributaria, ante el silencio reglamentario ${ }^{135}$, será órgano resolutor el mismo que lo fue para su incoación y para su instrucción.

En resumen, fuera de los casos en los que se trate de imponer sanciones de privación de derechos, que serán las menos, el órgano competente para la imposición de sanciones será el mismo que ha resuelto el procedimiento de regularización mediante el acto de liquidación, o bien el órgano superior inmediato del que ha propuesto el inicio del expediente de sanción ${ }^{136}$. Esto último sucederá en aquellos casos en que la sanción aparezca desligada de la liquidación, no ya en sentido puramente formal - que siempre lo estará-, sino en el sentido material, al tratarse de infracciones que no dan lugar a perjuicio económico inmediato.

\subsection{Competencia en los procedimientos de imposición de sanciones no pecuniarias}

Dicho procedimiento, regulado para los incumplimientos prevenidos por infracciones establecidas en el artículo 186 de la LGT, se desarrolla, a nivel reglamentario, en los artículos 30 y 31 del RD 2063/2004, de 15 de octubre. Específicamente, el artículo 31.2 del reglamento sancionador tributario prevé que el órgano que hubiese impuesto la sanción pecuniaria "propondrá la iniciación» del procedimiento sancionador (no pecuniario) mediante escrito dirigido al órgano competente para acordar su iniciación, acompañando copia de la diligencia o del acta extendida y de los demás antecedentes ${ }^{137}$.

En el caso de que la competencia para imponer la sanción no pecuniaria corresponda al Consejo de Ministros ${ }^{138}$, la competencia para

135 ESEVERRI..., 2011, op. cit. pág. 470.

136 PÉREZ ROYO, F.: Derecho Financiero ...2009, op. cit. pág. 427.

${ }^{137}$ Se advierte que aunque los apartados $1^{\circ}, 2^{\circ}$ y $3^{\circ}$ del artículo $186.1^{\circ}$ LGT hablan de "podrá» imponer además las siguientes sanciones accesorias, de carácter no pecuniario, el artículo 31.1. ordena que se incoe en caso de resultar acreditados los hechos y circunstancias que determinan la sanción, eliminando cualquier tipo de arbitrariedad. ANEIROS PEREIRA, J.: Las sanciones ...op. cit. pág. 36.

138 Según el artículo 211.5.a) de la LGT, el Consejo de Ministros es órgano competente para la imposición de sanciones si consisten en la suspensión del ejercicio de profesiones oficiales, empleo o cargo público. 
iniciar el procedimiento sancionador será del Ministro de Economía y Hacienda. En los demás casos ${ }^{139}$, será de aplicación lo dispuesto en el artículo 22 del RD 2063/2004, de 15 de octubre. Por tanto, la competencia para iniciar el procedimiento sancionador depende del tipo de sanción accesoria que vaya a imponerse.

No haciéndose previsión expresa, habrá que estar, en todo caso, al procedimiento sancionador con tramitación separada, para determinar la competencia para instruir el expediente, y así habrá que estar al artículo $23.1^{\circ}$ RGRST cuando norma que será órgano competente para instruir el procedimiento sancionador el que se determine en la normativa de organización aplicable, y a la competencia establecida en el art. $23.2^{\circ}$, sin perjuicio de las particularidades prevenidas en el artículo 25 de dicho reglamento para el caso de sanciones dimanantes de procedimientos de inspección.

Será competente en los procedimientos sancionadores iniciados por órganos de inspección, si se inició como consecuencia de un procedimiento de inspección, el equipo o unidad que hubiera desarrollado la actuación de comprobación e investigación, salvo que el inspector-jefe designe otro diferente. Si se trata de actuaciones inspectoras distintas de las que integran el procedimiento de inspección, será el

${ }^{139}$ Así el competente para iniciar el procedimiento para los casos previstos en las letras b), c) y d) del apartado $5^{\circ}$ del art. 211 de la LGT, será el Ministro de Hacienda, el órgano equivalente de las comunidades autónomas, el órgano competente de las entidades locales u órganos en quienes deleguen, cuando consista en la pérdida del derecho a aplicar beneficios o incentivos fiscales cuya concesión le corresponda (rogado) o que sean de directa aplicación por los obligados tributarios, o de la posibilidad de obtener subvenciones o ayudas públicas o en la prohibición para contratar con la Administración pública correspondiente (que le hubiere impuesto sanción pecuniaria); el órgano competente para el reconocimiento del beneficio o incentivo fiscal (rogado), cuando consistan en la pérdida del derecho a aplicar el mismo, salvo lo dispuesto en el párrafo anterior; Garberí considera que la pérdida del derecho a aplicar beneficios o incentivos fiscales a que refiere el art. 186 de la LGT sólo alcanza a los de carácter rogado y no a los que sean de directa aplicación por los obligados tributarios, por lo que parte de la competencia ministerial del art. 211.5.b) de la LGT quedaría vacía de contenido. Idéntica precisión debe efectuarse para con los beneficios e incentivos fiscales de carácter rogado que debemos entender refiere el art. 211.5'.c) LGT. En relación a los «beneficios o incentivos fiscales que sean de directa aplicación por los obligados tributarios» resulta sorprendente dado que la privación de este tipo de beneficios no se encuentra inicialmente dentro de las posibles sanciones pecuniarias que contempla la LGT. Sólo pueden perderse los beneficios o incentivos de carácter rogado, por referirse a ellos el art. 186 LGT y art. 30 RGRST. El resto de aplicación directa porque lo permita la norma tributaria (v.gr. deducción en IRPF por adquisición de vivienda habitual) no pueden ser objeto de sanción no pecuniaria basada en la aplicación de la LGT. MESTRE GARCÍA, E. y CERVANTES SÁNCHEZ-RODRIGO, C. J.: Guía de infracciones...op. cit. págs. 250 y 251. 
equipo o unidad que haya desarrollado las actuaciones de las que trae su causa la infracción ${ }^{140}$.

En los procedimientos sancionadores iniciados por órganos de gestión o de recaudación (diferentes a los órganos de la inspección) será órgano competente para iniciar el procedimiento sancionador el que se determine en la normativa de organización aplicable a los órganos con competencia sancionadora. En defectos de norma expresa, será el órgano competente el que tenga atribuida la competencia para su resolución.

En cuanto a la instrucción del procedimiento, la Ley 58/2003, no establece especialidad alguna, por lo que, según el artículo $31.1^{\circ}$ del RGRST, serán de aplicación las reglas que regulan la tramitación del procedimiento sancionador general, y habrá que entenderse hecha la referencia a la tramitación separada ${ }^{141}$.

\subsection{Conclusión. Necesidad de separación orgánica entre procedimientos de aplicación de los tributos y sancionador tributario}

En éste punto, aunque el objeto de este estudio no sea el análisis de la mencionada distribución competencial, nos parece interesante aludir a las diferentes posiciones que se han puesto de manifiesto en la doctrina con relación a este aspecto. Así, algunos autores ${ }^{142}$ consi-

${ }^{140}$ BLASCO DELGADO, C.:La prescripción ...op. cit. págs. 101 a 115.

${ }^{141}$ DÍEZ OCHOA, J.M.:Derecho Tributario...op. cit. pág. 551.

142 PONT CLEMENTE, J.F.: «El procedimiento sancionador tributario», RTT, núm. 51, octubre-diciembre, 2000, págs. 149 y 150. En este sentido también se han manifestado CERVERA TORREJÓN, F., MAGRANER MORENO, F., y JUAN LOZANO, A. M.: «Análisis crítico del Reglamento por el que se desarrolla el régimen sancionador tributario(RD 1930/1998)», $Q F$, núm.20, noviembre, 1998, pág. 18, quienes sostienen, críticamente, que existe una sucesión temporal entre el término de las actuaciones de comprobación e investigación, y la extensión del correspondiente acta, y el inicio del correspondiente expediente para sancionar; En esta línea, también se ha manifestado ANÍBARRO PÉREZ, S., que entiende que la solución más idónea, en orden a lograr una adecuada separación orgánica de los procedimientos de comprobación e investigación sería «... crear en el seno de la Agencia Estatal de la Administración Tributaria un Departamento al que se atribuyera específicamente la función sancionadora, distinto de los Departamentos de Gestión Tributaria, de Inspección Financiera y Tributaria y de Recaudación, el cual tendría encomendada la iniciación, instrucción y resolución de los expedientes sancionadores», y continúa señalando que "... en defecto de la anterior propuesta, sería al menos necesario garantizar que el funcionario, equipo o unidad que hubiera realizado las actuaciones de comprobación no fuera el mismo que aquel al que se encomienda la instrucción del procedimiento sancionador. Vid. ANÍBARRO PÉREZ, S.: «La separación de los procedimientos tributarios de comprobación y de imposición de sanciones cuestiones pendientes», $C T$, núm. 104, 2002, pág. 132. 
deran que para hacer efectiva la separación de los procedimientos de comprobación e investigación y sancionador es preciso independizar los órganos competentes en cada caso, por lo que sería preciso crear órganos sancionadores específicos, consagrando así la separación procedimental que se inició en la Ley de Derechos y Garantías de los Contribuyentes. Mientras tanto, otro sector de la doctrina${ }^{143}$ mantiene una posición más moderada considerando que la separación de órganos no es una exigencia que derive del artículo 34 de la ley $1 / 1998$, de 26 de febrero, actual artículo $208.1^{\circ}$ de la Ley $58 / 2003$, de 17 de diciembre, ya que este precepto sólo se refiere a la necesidad de expedientes separados y no a órganos independientes ${ }^{144}$, por lo que podrían ser los órganos de la gestión, inspección o

${ }^{143}$ En este sentido se ha manifestado, entre otros, BOTELLA GARCÍA-LASTRA, C.: «Análisis de la incidencia de los procedimientos sancionador y de liquidación tributaria a la luz de los resultados de las actuaciones de la inspección de los tributos en los últimos cuatro años», $C T$, núm. 104, 2002, pág. 147, cuando señala que ..... la introducción de órganos sancionadores específicos representa un coste administrativo de gran entidad que no resulta justificado, sobre todo si se tiene en cuenta la facilidad del acceso a los Tribunales Económico-Administrativos y la formación especializada de estos órganos, así como la suspensión automática de las sanciones sin necesidad de prestar garantía alguna»; Otros autores, como SÁNCHEZ PEDROCHE, J.A.:«Algunas cuestiones de interés atinentes a los derechos y garantías en el procedimiento sancionador tributario», $R C T-E F$, núm. 208, julio 2000, págs. 54 y ss., o SESMA SÁNCHEZ, B.: «Aspectos críticos de la nueva regulación del procedimiento sancionador tributario», $R T T$, núm. 42, 1999, págs. 116 y ss., aceptan el modelo por el que optó el RD 1930/1998, de 11 de septiembre.

${ }^{144}$ Así dicha separación entre instrucción y resolución podemos encontrarlas en algunos artículos, aunque en su contenido no se trate como tal separación orgánica, así los arts. 210 «Instrucción del procedimiento sancionador en materia tributaria» y 211 de la LGT "Terminación del procedimiento sancionador en materia tributaria» y 23 «Instrucción del procedimiento sancionador» y 24 del RGRST «Resolución del procedimiento sancionador»; Así la STSJ de Madrid de 18 de marzo de $2008\left(\mathrm{FJ}^{\circ}\right)$; Para otros autores, que van más lejos, indican que «una cuestión que ha planteado la doctrina ha sido la posibilidad de constituir un motivo de recusación del instructor del expediente sancionador el hecho de que sea el mismo funcionario que ha incoado el acta de inspección. La respuesta ha de ser negativa, ya que la LRJPAC [hoy LPACAP] no contempla en el procedimiento administrativo dicha situación entre los motivos de abstención o recusación. Tan sólo establece como garantía del ciudadano la estricta separación de procedimientos y el que dentro del procedimiento sancionador, la instrucción y la resolución correspondan a órganos diferentes (art. 134 LRJPAC [hoy art. 63.1 LPACAP]); garantías estas que fueron incorporadas al ámbito del procedimiento sancionador tributario por el art. 34 LDGC...y que en este asunto se respeta plenamente». AA.VV. (Coord. PELÁEZ MARTOS, J.M. ${ }^{a}$.): Todo procedimiento.. op. cit., 2006, pág. 1166; Estos autores citan la siguiente jurisprudencia: No es ilegal que el instructor sea el actuario si es el Inspector Jefe el que resuelve (STSJ Castilla y León 18.10.2002); Lo fundamental es la separación entre instrucción y resolución. No se lesiona ningún derecho si el inspector que ha liquidado es también el instructor del expediente sancionador (STS 18.12.1999). 
recaudación los que liquiden y sancionen siempre que se establezcan las cautelas necesarias para respetar las garantías del presunto infractor en cualquier procedimiento sancionador ${ }^{145}$.

${ }^{145}$ Concluye BLASCO DELGADO que de cualquier modo, si no es posible en los momentos actuales asumir el coste que supone la creación de órganos sancionadores específicos, al menos, como apunta ANÍBARRO PÉREZ sería deseable prever, como se ha hecho en el ámbito de la gestión tributaria la creación de una Sección de Procedimiento Sancionador, a la cual corresponde el inicio, tramitación y propuesta de resolución de los expedientes de imposición de sanciones por infracciones tributarias en vía de gestión; en efecto, esta solución podría ser una referencia a seguir en lo que atañe a la Inspección de los Tributos. BLASCO DELGADO, C.: La prescripción de las infracciones y las sanciones, Civitas, Madrid, 2003, pág. 104; Dicha Sección Sancionadora ha sido mantenida en la Resolución de 19 de febrero de 2004, de la Presidencia de la Agencia Estatal de Administración Tributaria, sobre organización y atribución de funciones en el ámbito de competencias del Departamento de Gestión Tributaria (BOE núm. 53, de 2 de marzo; corrección de errores en BOE núm. 64, de 15 de marzo) en su disposición quinta, apartado $4^{\circ}$, punto $2^{\circ}$, letra f) regula la Sección de Procedimiento Sancionador, cuya función es el inicio, tramitación y propuesta de resolución de los expedientes sancionadores por infracciones tributarias en vía de gestión tributaria, así como de intereses y recargos, en términos análogos a los de su creadora, la derogada Resolución de 24 junio de 1999, de la Presidencia de la Agencia Estatal de la Administración Tributaría, sobre organización y atribución de funciones en el ámbito de competencias del Departamento de Gestión Tributaria; Así la STSJ de Asturias de 16 de mayo de 2000, en un acta de inspección en disconformidad, que fue resuelta, en su condición sobrevenida de Inspector-Jefe, por la misma persona que había intervenido como actuario. La sentencia, por encima del argumento estrictamente formal de que el órgano de comprobación fue distinto del órgano que resolvió el expediente, da preferencia a la realidad material de que la persona que resolvió fue la misma que tramitó la comprobación. SIMÓN ACOSTA, E.: «Sanciones tributarias: separación entre órgano instructor y órgano sancionador», JT, 2000, BIB 2000\1875. 